\title{
Post-rift evolution of the Gulf of Lion margin tested by stratigraphic modelling
}

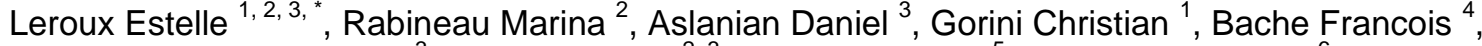 \\ Moulin Maryline ${ }^{3}$, Pellen Romain ${ }^{2,3}$, Granjeon Didier ${ }^{5}$, Rubino Jean-Loup ${ }^{6}$
}

${ }^{1}$ Univ Paris 04, Univ Paris 06, UMR 7193, Inst Sci Terre Paris ISTeP, F-75005 Paris, France.

2 IUEM, CNRS, UMR6538, Domaines Ocean, F-29280 Plouzane, France.

3 IFREMER, DRO GM LGG, F-29280 Plouzane, France.

${ }^{4}$ Santos Ltd, Melbourne, Vic 3001, Australia.

${ }^{5}$ IFP Energies Nouvelles, F-92852 Rueil Malmaison, France.

${ }^{6}$ CSTJF, TOTAL, F-64018 Pau, France.

*Corresponding author : Estelle Leroux, email address : stll.leroux@gmail.com

\begin{abstract}
:
The sedimentary architecture of basins and passive margins is determined by a complex interaction of parameters, including subsidence, eustasy, and sediment supply. A quantification of the post-rift (20 Ma-0 Ma) vertical movements of the Gulf of Lion (West Mediterranean) is proposed here based on the stratigraphic study of sedimentary paleomarkers using a large 3D grid of reflection seismic data, correlations with existing drillings, and refraction data. Post-rift subsidence was measured by the direct use of sedimentary geometries analysed in 3D and validated by numerical stratigraphic modelling. Three domains of subsidence were found: on the continental shelf and slope, subsidence corresponds to a seaward tilting with different amplitudes, whereas the deep basin subsides purely vertically. We show that these domains fit with the deeper crustal domains highlighted by previous geophysical data, and that post-break-up subsidence follows the initial hinge lines of the rifting phase. Subsidence rates are quantified on each domain for each stratigraphic interval. At a constant distance from the rotational hinge line, the Plio-Quaternary subsidence rate is constant on the shelf overall. Conversely, Miocene subsidence rates are very different on the eastern and western shelves. Stratigraphic simulations focused on the Messinian salinity crisis (MSC) were also performed. Their results are discussed together with our post-rift subsidence estimates in order to provide ideas and hypotheses for future detailed quantifications of Miocene subsidence, including isostatic readjustments linked to the MSC.
\end{abstract}

Keywords : Stratigraphic modelling, Seismic stratigraphy, Gulf of Lion, Post-rift subsidence, Messinian salinity crisis, Deep and surface processes 


\section{Résumé :}

Définir et quantifier les rôles relatifs des paramètres agissant sur l'architecture finale des bassins sédimentaires et des marges passives (subsidence, eustatisme, apports sédimentaires) n'est pas une tâche facile. La quantification des mouvements verticaux de la marge du Golfe du Lion (Méditerranée Occidentale) est ici proposée. Elle est basée sur l'étude stratigraphique des paléo-marqueurs sédimentaires identifiés sur un large jeu de données de sismique réflexion corrélés aux puits et données de sismique réfraction existantes. La subsidence post-rift est mesurée directement via les géométries sédimentaires analysées en 3D et validée par des modélisations stratigraphiques. Trois domaines de subsidence sont mis en évidence: sur la plate-forme et la pente continentales, la subsidence prend la forme d'un basculement vers le large avec une amplitude de basculement qui varie, tandis que le bassin profond s'affaisse de façon purement vertical. Nous montrons que ces domaines se corrèlent avec les domaines profonds mis en évidence par les études géophysiques et que la subsidence post-break-up réutilise les lignes charnière initiales du rifting. Les taux de subsidences sont quantifiés sur chaque domaine pour chacun de nos intervalles stratigraphiques. Ils révèlent un taux de subsidence constant à équidistance de la ligne charnière sur l'ensemble de la plateforme pendant le Plio-Quaternaire. Au contraire, les taux de subsidence sont complètement différents pendant le Miocène entre la plate-forme occidentale et la plate-forme orientale. Des simulations stratigraphiques focalisées sur la crise de salinité messinienne ont également été réalisées. Ces résultats sont discutés conjointement à nos quantifications de subsidence post-rift notamment dans le but de fournir des hypothèses ou éléments pour, à l'avenir, quantifier plus précisément les mouvements verticaux au sein du Miocène et notamment l'amplitude des réajustements isostatiques liés à la Crise de Salinité Messinienne.

Mots-clé : Modélisations stratigraphiques, stratigraphie sismique, Golfe du Lion, Post-Rift subsidence, Crise de Salinité Messinienne, processus profonds et superficiels 


\section{Introduction}

Defining and quantifying the relative role of parameters interacting to produce the final sedimentary architecture of basins, including subsidence, eustasy, sediment supply, and tectonics, is not an obvious task. This has been one of the main goals of seismic and sequence stratigraphy, as developed in the early 80's (e.g. Mitchum and Vail, 1977; Posamentier et al., 1988a). At the same time, the quantitative techniques of geological analysis of sedimentary basins (geohistory analysis) were developed (e. g. Allen and Allen, 1990; Jervey, 1988; Robin et al., 1996; Van Hinte, 1978). These techniques are used to produce a curve for subsidence and sediment accumulation rates through time. This backstripping method depends on theoretical or empirical laws and assumptions (e.g. Airy vs regional flexure), as well as a number of corrections (compaction, paleobathymetry, and absolute sea-level fluctuations) based on available datasets. Here, a different method is applied to quantify subsidence and sediment fluxes with the direct use of sedimentary paleomarkers (Rabineau et al., 2014; Leroux et al., 2014).

The subsidence of the recent (Neogene) Provençal Basin is still underway and enables progressive filling of the basin which preserves a record of shoreline migrations (landward and seaward) associated with the rise and fall of sea levels, as well as a record of vertical movements of the margin (Rabineau et al., 2006, 2014). These favorable conditions, together with industrial boreholes and the large seismic database available on the Gulf of Lion margin (including conventional seismic lines, high-resolution multi-channel data, and very high-resolution profiles), render this basin an ideal candidate for constraining the vertical evolution of rifted continental margins using the sedimentary record. This paper summarizes this 3D post-rift evolution and discusses its validation by three-dimensional stratigraphic modelling.

\section{Data and methods}

\subsection{Data}

The stratigraphy of the Gulf of Lion and the Provence Basin has been studied at various time scales, from the syn-rift phase (e.g. Gorini, 1994; Guennoc et al., 2000), Oligo-Miocene (Mauffret et al., 1995; Bache, 2008), through the Pliocene and Quaternary (e.g. Lofi et al., 2003; Duvail et al., 2005), and up to the last $500000 \mathrm{yr}$ (Bassetti et al., 2008). Until now, most of the studies have focused on specific areas of the margin (the shelf or the deep basin), as establishing stratigraphic continuity between the shelf and the basin is hampered by the existence of numerous canyons incising the upper slope (e.g. Baztan et al., 2005), and a robust correlation has never been completely elucidated.

This study used a set of seismic data developed during the French "GDR Marges" and "Actions Marges" Programs, thanks to the collaboration of TOTAL, which allowed access to all their conventional seismic lines, high resolution multi-channel data, and industrial boreholes. Additional high and very high-resolution seismic profiles from IFREMER, IFP, and CNRS were also used (Figure 1). Nine boreholes drilled between 1969 and 1985 in the Gulf of Lion enabled correlation and validation of seismic interpretations. Seven of them are located on the shelf. Autan 1 and GLP2, are located on the upper and lower slope (Figure 1), respectively. Stratigraphic, sedimentologic, and micropaleontological analyses (Cravatte et al., 1974) of Autan 1, Mistral 1, Tramontane 1, and Sirocco 1 boreholes provide insights on the depositional environments. The wide-angle seismic data from the 1D-ESP (Expanding Spread Profiles: Le Douaran et al., 1984; Pascal et al., 1993) and from the 2D-OBS (SARDINIA; Gailler et al., 2009; Aslanian et al., 2012; Moulin et al., submitted this issue; 
Afilhado et al., submitted this issue) also enable quantification of velocities and thicknesses of sediment and crust series in the deep basin.

\subsection{Methods}

Most authors recognize three constantly evolving factors that directly control the creation, expression, and organization of sedimentary sequences (Vail et al., 1987; Jervey, 1988; Posamentier et al., 1988, Posamentier and Vail, 1988; Guillocheau, 1991...): (1) eustasy (with absolute sea-level variations), (2) sedimentary fluxes, and (3) vertical movements of the substratum (subsidence and compaction). Each of these factors needs to be quantified through time and represent the three major input parameters for stratigraphic modelling.

Sequence stratigraphy conceptual models (e.g. Jervey, 1988; Posamentier et al., 1988a \& 1988b; Catuneanu et al., 2009, among many other references) are very helpful for analyzing the sedimentary record, testing hypotheses, and deciphering the relative role of accommodation and sediment supply. Stratigraphic forward numerical models have been developed since the early 1960 s to test these conceptual frameworks and to facilitate understanding of the role of each parameter on the overall stratigraphic architecture. Models aim to reproduce the three-dimensional dynamics of sedimentary systems, their landscape, and the stratigraphic record. Such models allow us to quantify the role and interaction of tectonics and sedimentary processes, to test different interpretations of seismic data and geological scenarios, and thus to reduce uncertainties in the interpretation of the preserved stratigraphic architecture.

Here, we used a process-based modelling tool developed at IFP-Energies Nouvelles: DIONISOS (Granjeon, 1996, 2009; Granjeon \& Joseph, 1999; Granjeon \& Wolf, 2007). It is a diffusion process-based simulation model that can account for sea-level change, tectonics (e.g. subsidence, flexure, compaction, and salt diapirism), sediment supply (e.g. basement and sediment erosion, fluvio-deltaic siliclastic input, carbonate production, and evaporite precipitation), and sediment transport (e.g. rivers, waves, and gravity flows). The model assumes that the upscaling of local-scale transport processes leads to a large-scale fluvial transport equation, which can be written in the form of a diffusion equation.

In our simulations, eustasy is taken from Haq et al. (1987) and Miller et al. (2005), modified by a significant drawdown during the Messinian Salinity Crisis (MSC) (Clauzon, 1982) (Figure 2A). Seismic stratigraphy principles were used to interpret seismic profiles (Payton, 1977). Key reflectors were identified, dated (from wells), correlated at a regional scale, and converted in depth using ESP and sonic data from wells. Basement, Messinian units, and Pliocene and Pleistocene chronostratigraphic markers were correlated from the shelf to the footslope. This allowed us to generate isobath and isopach maps and quantify sediments fluxes for the entire Gulf of Lion post-rift margin (Leroux, 2012; Leroux et al., 2014).

The seismic velocities vary strongly in space within the same stratigraphic interval, with important differences between the shelf, the slope, and the deep basin. Wide-angle data were acquired in the basin during the Sardinia cruise. Together with ESP velocities and sonic logs of the drillings on the shelf, these data were jointly analyzed and used to establish a 3D map of seismic velocities for each stratigraphic interval. The interpolation of these velocities with a regular and relatively restricted step (every $100 \mathrm{~ms}$ twtt) allowed us to avoid abrupt velocity transitions. We then depth-converted previous isochron maps of all our stratigraphic units, re-drew all isopach maps in meters (as shown in Leroux, 2012), and calculated volumes for compacted sediments.

For each unit, we defined i): the proportion of dominant facies from well data (shale, sand, and carbonate), and ii): the mean burial depths from seismic profiles. With the exception of 
well GLP2, which is on the slope, a regional mean compaction law cannot be derived from the other wells that are mainly located on the shelf. We therefore built a compaction law using the GLP2 sonic data, assuming that it represents porosity versus depth. The sonic curve mirrors the evolution of the seismic velocities within all sediment lithologies. Sediments bored by GLP2 were mostly shale and fit the median curve of the compaction interval given by Allen \& Allen's (2005) abacus curves, therefore we used this as the compaction law for shale.

We are confident that the median curves of the compaction intervals given by Allen \& Allen's (2005) abacus curves for the other lithologies (sand \& carbonates) are also suitable for the decompacted sandy and carbonated fractions in our study area. Then, assuming that the decrease in volume is equal to the reduction of porosity, we estimated the porosity loss for each facies and unit, and calculated the decompacted volumes from the compacted ones deduced from our isopach maps. These volumes were finally assigned to a time-span and sediment fluxes were calculated.

Detrital and evaporitic parts have been distinguished and quantified for each stratigraphic unit using well data and interpreting the seismic facies in the basin. The Messinian evaporitic part was distinguished from detrital sediments when it could be quantified (i.e. for the halite layer). The resultant sediment supply history (Figure 2B) was used as an input into the DIONISOS numerical stratigraphic model.

Ten synthetic lines were also extracted from the set of isobath maps (Figure 3). We then built vertical dip and strike sections in order to quantify the three dimensional vertical evolution and potential tectonic deformation of the margin. We applied a new method to quantify the post-rift subsidence with the direct use of sedimentary geometries as described in Rabineau et al., 2014. On each section, we have adjusted the paleo-erosional surfaces to straightlines, analysed their tilt and quantified angle of tilt and their subsidence rates (see Figure 4). This reconstructed 3D subsidence history will be the third major input parameter into the DIONISOS model.

The basin is simulated as a rectangular grid $(450 \mathrm{~km} \times 250 \mathrm{~km})$ with a $5 \times 5 \mathrm{~km}$ mesh. The first post-rift deposits are dated around 20 Ma (De Voogd et al., 1991; Séranne, 1999). Simulations were run over the last $23 \mathrm{Ma}$ with a $0.1 \mathrm{Ma}$ time-step. We considered three main sources of sediments (river mouths), the Rhône, the Languedoc rivers, and the Pyrenean rivers (Aloisi, 1986; Radakovitch, 1995; Durrieu de Madron et al., 2000), which deliver respectively $65 \%, 30 \%$, and $5 \%$ of the total amount of sediments in the Gulf of Lion. These were defined taking into account the relative size of the present-day Rhodanian catchment area versus the Languedocian drainage system and the average loads of total suspended solids of the Rhône, Aude, Hérault, Orb, and Têt rivers (Roussiez et al., 2005 from Pont (1997); Sempéré et al. (2000); Pauc (1976); Serrat et al. (2001); Garcia-Esteves \& Ludwig (2003)). Input lithologies are partitioned into $70 \%$ clays and $30 \%$ sands according to logs from petroleum wells on the shelf and slope (Tramontane1, Agde1, Calmar1, Sirocco1, Mistral1, Rascasse1, Autan1, and GLP2) (see Figure 01). Diffusion coefficients are calculated for each lithology (sand, clay, and evaporite) from mean slope and water flux (characterizing the transport efficiency) in different environments, see Granjeon \& Joseph (1999) for a detailed description of the model, transport laws and parameters. 


\section{Results}

\subsection{Estimation of subsidence}

\subsubsection{Shelf}

We first focused our subsidence analysis on the shelf, using dip sections $B, C$, and $E$ (Figure 4). We analysed the post-Messinian sequence overlying the Messinian Erosional Surface (MES), whose rough topography corresponds to fluvial erosional processes during the MSC. We approximated the envelope of the topsets of Pliocene (MES and P11) and Pleistocene (PXX, Q10, Q5, and sea-floor) seismic reflectors as straight-lines, both on the inner and outer part of the platform, following the methodology proposed by Rabineau et al., (2014) for the LRM18 2D line. In this work we did the same analyses on 10 regional synthetic lines, enabling us to draw a subsidence map for the entire margin. We also positioned observed offlap breaks on the depositional prisms (i.e. at the transition between topsets and foresets). These offlap breaks correspond to the position of the shelf break and are represented with shaded squares on Figure 4.

Our 3D analysis for the Pliocene and Pleistocene shelf shows that all lines basically follow the same organization with erosional surfaces that are inclined seaward, with a slope that increases with the age of the reflectors. All lines also have a common rotation point located around $20 \mathrm{~km}$ landward of the present-day coast (varying from one section to another, but all within a range of a few kilometers). The tilting of the margin for the last $5.33 \mathrm{Ma}$ (between the MES and the present-day-seafloor i.e. since the end of the MSC) can be measured directly on the profiles and is surprisingly quite constant from one line to the other: it reaches around $1,300 \mathrm{~m}$ at the shelf edge (Hinge Line 2). Tilting subsidence implies an evolution of the rate of vertical movement along the surface: subsidence rate is null at the hinge point and increases progressively with the distance from the hinge point. The use of tilt rate in $\% \mathrm{Myr}$ allows us to describe this evolution with respect to the distance from the hinge point and compared with other tilted margin. The conversion of tilting subsidence (degree per Myr) to vertical subsidence $(\mathrm{km}$ per Myr) at a point across the margin is given by: $b(\mathrm{~km} / \mathrm{Ma})=a$ (distance from hinge point) ${ }^{*} \tan \alpha$ (cf. Rabineau et al., 2006).

The angle of Pliocene and Pleistocene tilt is therefore $\alpha=0.88^{\circ}$ i.e. a mean tilting subsidence rate of $\alpha=0.16^{\circ} / \mathrm{Myr}$ for the last $5.33 \mathrm{Ma}$.

Seismic reflectors have been identified and correlated with boreholes; ages of these paleomarkers have been estimated using biostratigraphic data from boreholes: the respective surfaces Q5, Q10, PXX, and P11 have then been dated to $0.45 \mathrm{Ma}, 0.9 \mathrm{Ma}, 1.6$ 1.8 $\mathrm{Ma}$ and 2.6 Ma, respectively (Leroux et al., 2014). Considering these ages, we can calculate Pliocene and Pleistocene subsidence rates, but also the evolution of the tilt within the Pleistocene. Deposited sediment thickness for each stratigraphic interval is indicated for each section (Figure 4) as well as the duration of the interval. This allows us to quantify five successive tilts throughout the last $5.33 \mathrm{Ma}$ : from $5.33 \mathrm{Ma}$ to $2.6 \mathrm{Ma}$; from $2.6 \mathrm{Ma}$ to $1.6 \mathrm{Ma}$; from 1.6 Ma to $0.9 \mathrm{Ma}$, from $0.9 \mathrm{Ma}$ to $0.45 \mathrm{Ma}$, and finally from $0.45 \mathrm{Ma}$ to present-day. We calculated the same angle of tilt for each of these stratigraphic intervals, $\alpha=0.16^{\circ} / \mathrm{Myr}$, which shows that subsidence rate has been constant through time for the last $5.3 \mathrm{Ma}$.

This is consistent with the two-dimensional estimation of subsidence from Rabineau et al. (2014) on the LRM18 seismic profile (see position on Figure 3) and two-dimensional stratigraphic modelling (Leroux et al., 2014). 
Secondly, we calculated the mean post-rift subsidence on the shelf. As for the younger surfaces, the geometry of the basement is (approximately) integrated to a straight line, barring the morphologies of the local horsts and grabens of the basement (such as the central graben), to find its best fit straight-line adjustment as illustrated on Figure 4 . This best fit line intersects the same rotation point as for the Pliocene and Pleistocene markers. We therefore estimated a basement tilt with an angle $\alpha$ ranging between $0.11 \% \mathrm{Myr}$ and $0.12^{\circ} / \mathrm{Myr}$ (sections B and C) and $\alpha=0.06^{\circ} / \mathrm{Myr}$ (section E). This means that the Miocene subsidence rate of the platform varies in space, with higher values on the western part of the Gulf of Lion. The Rhodanian basement seems to have experienced a weak tilting subsidence rate during the Miocene. These Miocene rates also imply an increase of tilting subsidence on the shelf during the Pliocene and Pleistocene.

\subsubsection{Deep basin}

On all sections of Figure 3, we positioned the slope breaks observed on the entire margin (shaded circles on Figure 5) for each of our seismic horizons (from substratum to seafloor). Four dip sections (B, C, D, and E) are illustrated on Figure 5. Their locations highlight the three hinge zones (grey areas) that mark three domains (shelf, slope, and deep basin), characterized by three different subsidence modes. The paleomarkers on the shelf and the slope are tilted, however the respective rotation point and the angle of their tilt differ. Moreover, in the deep basin seaward of hinge zone 3, paleomarkers appear horizontal and parallel to each other. We infer that the distal part of the margin has been submitted to a purely vertical subsidence. Note that in this case, unlike tilting subsidence, all

points of a surface subside at the same rate along the vertical with no horizontal displacement. The movement is thus described by a subsidence rate in $\mathrm{m} / \mathrm{Myr}$.

In order to calculate the amount of total and incremental subsidence, we need to know the initial position of the margin at the end of the rifting in this domain. Bache et al. (2010) observed subaerial erosion at the top of the thin Oligocene-Lower Miocene syn-rift deposits or directly on the basement, that could be followed down to the present-day foot of the slope. This demonstrates that the margin held a high position throughout the entire rifting period, with little or no syn-rift subsidence. This therefore implies that the initial morphology of the margin at the end of the rifting phase was characterized by a paleobathymetry close to or above sea-level, and can therefore be used as an initial morphology for the simulation. This, in turn allows us to estimate a mean post-rift subsidence rate of $500 \mathrm{~m} / \mathrm{Myr}$.

\subsubsection{Slope}

Tilt estimates on the slope are difficult to quantify because clear sedimentary markers such as breaks in slopes are lacking. Seismic geometries may provide clues, however the observed tilt of successive sequences might not be consistent with a progressive seaward tilting. Moreover, isotatic adjustment linked to the MSC introduced more uncertainties (also on the shelf and in the deep basin). However, sedimentary markers display an angle across the shelf-slope and slope-basin transitions. Therefore, subsidence on the slope gradually accommodates differential movements on both sides.

\subsubsection{Three- dimensional synthesis}

The analysis of vertical movements using the stratigraphic record allowed us to draw a map of the post-rift subsidence in the Gulf of Lion (Figure 6A). Subsidence rate values are plotted on a geographical frame for each domain (shelf, slope, and deep basin). The three HingeLines (or Hinge Zones) we identified are also located on the map. The first one (HL1) 
corresponds to the initial points of the tilt for the shelf segment, i.e. the rotation point along the margin. Note that this rotation is localized at a remarkably constant average distance of $20 \mathrm{~km}$ landward of the present day coast in the Herault and Roussillon Areas. This is not true for the Camargue area, since HL1 correlates with the Nimes Faults and the present-day coastline results only from the recent Rhone progradation (so that the distance between present-day coast and HL1 is greater). The second Hinge Line (HL2) (on map, Hinge Zone 2) corresponds to the position of successive paleoshelf-breaks. The third Hinge Line (HL3) is located at the transition between the slope (which is tilted) and the deepest basin that subsides purely vertically as a sag-basin.

Independent work (Figure 6B) based on geophysical analysis of deep penetrating reflection and refraction data (ECORS data and Sardinia data) also showed different domains of the margin with different types of crust (De Voogd et al., 1991; Pascal et al., 1993; Gorini et al., 1994; Séranne et al. 1995; Séranne, 1999; Aslanian et al., 2012; Moulin et al., this issue).

- a landward first domain characterized by weakly thinned continental crust.

- a second one with strongly thinned continental crust.

- a third transitional domain whose crustal nature is still unknown.

- a fourth domain corresponding to the oceanic crust.

Hinge Lines correlate with the limits of the underlying structural domains highlighted by geophysical data (Figure 6B). HL1 separates thinned and unthinned continental crust. HL2 is located at the end of Domain 1 and at the beginning of Domain 2 (with a highly thinned continental crust). HL3 is located at the end of Domain 2 and at the beginning of Domain 3 (with an atypical crust). In other words, the more or less thinned continental crust domain (1 and 2) is tilted whereas the atypical crustal domain (3) subsides purely vertically. So, the post-break-up subsidence re-uses the initial hinge lines of the rifting phase.

\subsection{Three-dimensional post-rift modelling}

We ran three-dimensional modelling in order to test the post-rift subsidence history that we built on the basis of our very precise data (segmentation, tilting/pure vertical, variation). We attempted to reproduce the geometries and thickness of the sediment on the shelf, slope, and basin, using a 3D model of subsidence, as we did in 2D for the shelf of the Gulf of Lion during the Pliocene and Quaternary period. In that particular period for instance, we were able to show that a strong variation in subsidence fails to reproduce the geometries (Leroux et al., 2014).

\subsubsection{Post-rift}

We simulated the sedimentary filling during the last $20 \mathrm{Ma}$ with a $0.1 \mathrm{Ma}$ time-step. The sediment detrital supply history (Figure 2B) (Leroux, 2012) and the quantitative evolution of post-rift subsidence (Figure 6) are used as input parameters into the DIONISOS software. Two modellings were run successively using the two sea-level curves from (1) Haq et al., (1987) then (2) Miller et al., (2005) (Figure 2), modified by a $1500 \mathrm{~m}$ drawdown during the Messinian Salinity Crisis (MSC) (Clauzon et al., 1982).

Figure 7 compares the observed architecture as seen on seismic profiles $(A)$ with the final architecture of the margin and the predicted paleodepths as reproduced by the model (B1, B2, C1, and C2) with the two sea-level variations scenarios (see the curves in Figure 2). 
Outputs from the simulation (Figures 7B and C) show that whatever the sea-level scenario taken into account, a shelf-slope basin morphology is progressively created during the postrift Miocene with creation of accommodation after $20 \mathrm{Ma}$ related to the opening of the Provencal basin. After rifting, the entire Gulf of Lion margin was indeed affected by strong post-rift subsidence. The simulated pre-Messinian basin reaches $3100 \mathrm{~m}$ depth. Then, at the onset of the Messinian salinity crisis (MSC) (5.96 Ma) the sea-level drops (in one or two steps). Details about the scenarios of the MSC are multiple and controversial (e.g. CIESM, 2008). Our intention in this paper is not to review the different models and their details. Therefore, we tested a simplified model for the MSC with a single but major drawdown (1500 $\mathrm{m}$ ) starting at $5.96 \mathrm{Ma}$ to test the effect of such a sea-level variation (3000 m/Myr rate of drawdown) on erosion and sedimentation.

During the drawdown, the shelf and slope are the focus of very strong fluvial erosion. Products of this erosion are deposited seaward as forced regressive prograding prisms located at the foot of the slope.

This is very well seen in the simulation (B1 and B2), with thick detrital prisms that reach around $1 \mathrm{~km}$ in thickness. During the MSC, salt is precipitated in a dessicated basin (red paleobathymetries in Figures 7B1, B2, C1, and C2) using a simple deterministic module for salt deposition.

The simulated deposits in the basin include detrital and salt but the time-step ( $0.1 \mathrm{Ma})$ here is too large to have resolution during the short duration $(0.63 \mathrm{Ma})$ of the crisis, thus the model cannot reproduce real sediment geometries. So, another simulation focused on the Messinian will be detailed hereafter. At the end of the crisis (5.33 Ma) the sea level rises and the platform is reconstructed during the Pliocene and Pleistocene. The prograding pattern between 5.33 and 2.6 Ma followed by a prograding-aggrading trend after 2.6 Ma (yellow marker on Figures 7B1, and C1) is observed on seismic profile (yellow offlap break in Figure 7D) and is also successfully reproduced by our 3D stratigraphic modelling. Therefore, the overall sediment architecture of the margin is well reproduced by the numerical model. Synthetic seismic lines were extracted from each simulation (Figures $7 \mathrm{C} 1$, and C2). The impedance contrasts (in red and blue in $\mathrm{C} 1$ and $\mathrm{C} 2$ ) highlight the major stratigraphic discontinuities we have observed on the seismic profile (compare $C 1$ and $C 2$ to Figure $7 A$ ). Notice that the depth of the final simulated basement reaches around 11,000 m deep in the basin, which is also the present-day mean basement depth observed on line-drawings (cf. also Figure 5). Sediment thicknesses above basement measured from seismic data are compared to the total sedimentary thicknesses extracted from the simulations on Figure 8 (with the same color scale). We can see that our simulation successfully reproduces the order of magnitude of the total post-rift thickness map, even if local thickening of deposits (as in the central graben on the shelf for example) is not visible. This is due to the flat paleomorphology adopted as an initial morphology of our basement (at $20 \mathrm{Ma}$ ).

We also note that the relative thicknesses of the stratigraphic intervals on the synthetic seismic line (Figures 7C1 and C2) extracted from the simulations do not seem to correspond to real thicknesses observed in the basin: simulated deposits during pre-Messinian Miocene sequences are too thick compared to the infilling of the Messinian basin. Modeled Pliocene and Pleistocene deposits also appear too thin relative to Miocene deposits. We will now discuss the potential explanations for this phenomenon.

If we analyse the influence of sea-level curve input in the model, the first notable thing is that both simulations are very similar for the Pliocene and Pleistocene, whereas they differ for the Miocene and Messinian (see the predicted paleobathymetries and geometries on Figures 7B and $\mathrm{C}$ ). This is easily explained by the higher differences of the amplitudes of sea-level 
variations between the two curves for the $20 \mathrm{Ma}-5 \mathrm{Ma}$ interval. For Haq et al. (1987), mean sea-level highstand during the Aquitanian-Burdigalian-Langhian is around $+120 \mathrm{~m}$, while it is only around $0 \mathrm{~m}$ for Miller et al. (2005). This is clearly seen on the simulation, as B1 shows much deeper paleobathymetry at the beginning of the simulation as compared to B2. Another strong difference is that the Haq et al. curve also shows a very strong sea-level fall from the mid-Langhian to the lower Tortonian where sea-level reaches $-80 \mathrm{~m}$. On the contrary, for that time period, Miller's curve is still around $0 \mathrm{~m}$. Surprisingly, this difference in sea-level curve is not so obvious in the output of the simulation.

The difference of resolution between the two curves does not significantly change the architecture of the margin at the post-rift time-scale, especially as the resolution of the curve is in fact reduced to $0.1 \mathrm{Ma}$ (the time-step of simulation). Miocene deposits on the shelf have shallower bathymetries (yellow on Figures 7B1 \& B2) and are also thicker with Miller's curve, but conversely are thinner in the deeper basin. It is interesting to note that the corresponding simulated erosional discontinuity for the base of the Messinian event is also located deeper than the one resulting from the simulation with Haq's curve.

\subsubsection{Messinian modelling}

Figure 7 is devoted to the entire subsidence history. The time-step for the simulation of postrift evolution of the Gulf of Lion margin is $0.1 \mathrm{Ma}$ (a compromise chosen between the time and space scales of the basin and the time-machine). This time-step is too large to distinguish Salt and Upper Unit simulated deposits given the duration of the crisis $(630,000$ years). In contrast, on Figure 9, which is devoted to the MSC, the time-scale for the simulation is reduced to 10,000 years. While it allows us to simulate in detail the stratigraphic architecture and testing hypotheses, the timing of the evaporitic production, including halite, is badly constrained and the lithology of the lower unit is still unknown. Coupling the stratigraphic simulation with a geochemical model for which all the parameters controlling evaporitic precipitation would be constrained (concentrations, influx, and climatic parameters) may allow us to distinguish between Halite and Upper Unit deposits and model the evaporite deposits in more detail. However, the nature of the sediment below the salt remains unknown, which imparts a strong uncertainty in the modelling. Due to these complications, we simplify the history of evaporitic production (including halite) to a constant rate of mixed salt and evaporite deposition: the beginning of evaporitic production (including halite) starts at the maximum of sea-level fall and continues during the beginning of sea-level rise over a period of 300,000 years.

The interpretation of Messinian deposits in the basin is still under discussion: while the Bache et al. (2009) interpretation proposes a very thick Messinian sequence below the evaporites, Lofi et al., (2011) suggest a thinner Messinian sequence and consequently a thicker Miocene interval. Equally debated are the exact timing and amplitude of sea-level fall and reflooding (Bache et al., 2012). In this paper, our simulations test the Bache et al. (2009) and (2012) interpretations.

A constant sediment flux of $51,000 \mathrm{~km}^{3} / \mathrm{Myr}$ is used as an input parameter in the numerical model. This value corresponds to the sediment supply history for the crisis (Leroux, 2012) calculated using 3D isopach maps of seismic units (Figure 2B). We also considered 100,000 $\mathrm{km}^{3}$ of evaporitic production, which corresponds approximately to a salt layer of $1 \mathrm{~km}$ thick spread over the defined $450 \mathrm{~km} \times 250 \mathrm{~km}$ basin. A constant tilting subsidence rate $(\alpha=$ $0.16^{\circ} / \mathrm{Myr}$ from hinge-line 1 ) is also used as an input parameter on the shelf, and a purely vertical subsidence rate of $500 \mathrm{~m} / \mathrm{Myr}$ is used in the deep basin. The pre-Messinian morphology of the margin is considered to be similar to the present-day shelf-slope-basin morphology, with a 3,500 m deep initial basin according to the results of backstripping from 
Bache (2008). We notice that this depth is in agreement with the hypothesis of a deep preMessinian basin according to Lofi, (2002) and Clauzon et al. (1996). It is also along the same lines as the depth of the pre-Messinian basin obtained by the previous simulation in this study $(3,100 \mathrm{~m})$. We have adopted the sea-level scenario from Bache et al. (2012) with a strong sea-level drawdown of $1500 \mathrm{~m}$ and a two-step reflooding: the first is slow and the second is very fast. The objectives of the numerical stratigraphic modelling are not to argue for or against different scenarios, but are to test quantitatively the effect of the Bache et al. scenario, together with our subsidence estimate and our calculation of sediment input, in order to determine whether or not we are able to reproduce the overall geometries of the deposits and architecture of the margin.

The results of this modelling are compared to seismic data as shown on Figure 9. During the $1,500 \mathrm{~m}$ sea-level drawdown, the model simulates the upstream erosional processes by Messinian rivers and respectably reproduces the Messinian Rhodanian and PyreneoLanguedocian canyons. We can also see that a large amount of Messinian detritals are deposited on the slope and in the basin as suggested by Bache, (2008) and Bache et al., (2012). The combination of a large sea-level drawdown, average subsidence rate for the margin (see previously), and high sediment flux correctly reproduces (without any further parameter changes) the observed thicknesses and geometries for the Messinian deposits. During the first slow step of reflooding, the reliefs of the initial Messinian Erosional Surface (MES) are progressively further eroded from downstream to upstream during the transgression. This corresponds to a flat abrasion surface in the prolongation of the MES on the seismic profile (Figure 9A). Transgressive deposits are also reproduced on the slope. They might correspond to the residual products of marine ravinement as interpreted on seismic lines in Leroux, 2012. By contrast, during the second step of reflooding which is very fast, the rough morphology of the MES is well preserved from further erosion.

The predictions of Messinian deposit geometries and paleobathymetries during the MSC (Figure 9C) have been extracted along a two-dimensional regional profile located on the western part of the margin and combined with a synthetic seismic signal to produce a pseudo-seismic image based on simulated geometries and lithologies. This NW-SE synthetic pseudo-seismic image (Figure 9B) can therefore easily be compared to the real one (Figure 9A). On the synthetic pseudo-seismic line, the impedance contrasts (in red and blue scale) highlight the same discontinuities that were observed on the seismic profile. The major discontinuities (base of Messinian, MES, and the abrasion surface) and the internal seismic reflections are also well reproduced by the numerical simulation. Besides, the thickness of the Messinian deposits that reach more than $2500 \mathrm{~m}$ in the basin, with around $700 \mathrm{~m}$ of early detrital deposits ( $\mathrm{M}$ unit) covered by more than $1500 \mathrm{~m}$ of lower evaporites and halite in the basin, is also coherent with observation on seismic profiles by Bache et al. (2009). On the slope, the detrital deposits ( $M$ unit) reach more than $1500 \mathrm{~m}$ on seismic profiles (almost 2000 $\mathrm{m}$ on the simulation) before its upper part laterally changes from a detrital facies towards an evaporitic facies.

We notice also that the Messinian incised valleys on the internal shelf are (partially) filled during the sea-level rise at the end of the MSC. This simulation also involves a mean Messinian erosion rate of 2,200 m/Myr. This rate is high when compared to the usual erosion rate over long time-scales (around 500 and 1000 m/Myr (e.g. Bigot-Cormier, 2000; Hinderer, 2001; Cederbom et al., 2004)). However, this value is similar to the one adopted by Rabineau (2001) and Rabineau et al. (2005) for her Quaternary stratigraphic simulations. We discuss here a unique and exceptional event whose amplitude is one order of magnitude greater than "usual" sea-level fall and erosion values averaged over a million years. Besides, relatively recent thermochronology works (Glotzbach et al., 2011) indicate alpine erosion rates reaching $2000 \mathrm{~m} / \mathrm{Myr}$ over the last $1.6 \mathrm{Ma}$. 
The exact timing and amplitude for the base-level fall as well as the reflooding and timing and amplitude of evaporitic precipitation during the MSC still need to be detailed. However, our results from the numerical simulation enabled us to test the plausibility of the Bache et al, 2009 interpretation. In particular, we tested the ability of the model to reproduce the early $1,500 \mathrm{~m}$ thick detrital and the total Messinian thickness of almost 3,000 $\mathrm{m}$ as proposed by Bache (2008). The Messinian modelling is in agreement with the Bache et al. interpretations, however it does not mean that other interpretations, like Lofi et al. for the base of the Messinian, are excluded.

\section{Discussion}

The stratigraphic modelling results, assuming a constant subsidence $(500 \mathrm{~m} / \mathrm{Myr})$ in the deep basin throughout the entire history, fit very well with the sedimentary geometry, thickness, and facies of the Plio-Pleistocene sequence on the shelf. However, they fail to correctly reproduce the sediment thicknesses observed on seismic profiles in the deep basin: while the overall modelled thickness fits the observed one $(\sim 8000 \mathrm{~m})$, the simulated Miocene and Plio-Pleistocene intervals are respectively thicker $(\sim 7000 \mathrm{~m})$ and thinner $(\sim 1000 \mathrm{~m})$ than observed (respectively ( 6000 m \& $\sim 2000 \mathrm{~m}$ ).

As previously mentioned, the interpretation of the base of the Messinian deposits in the basin is still controversial. According to Lofi et al. (2011) the pre-Messinian Miocene sediment volume is higher than in Bache et al. (2009). However, the Plio-Pleistocene sediment volume is similar for the two interpretations. The two hypotheses mainly impact the value of Messinian flux, due to the short duration of the event $(700,000 \mathrm{yr})$. Their impact on flux of pre-Messinian Miocene, which has a duration of $15 \mathrm{Myr}$, is much less important. Note that in any case, the sediment flux during the Pliocene (after $5.33 \mathrm{Ma}$ ) remains much higher than the flux in the pre-Messinian Miocene.

Three hypotheses can thus be investigated to explain the mismatch between the observed and modelled Miocene interval: 1) the ratio of terrigenous/carbonate in the calculated volumes of sediment, 2) a change in the respective contribution of the 3 river systems (Rhone, Languedoc Rivers, and Pyrenean Rivers) which are assumed to be constant over time, and with current respective values, and 3 ) a change in subsidence rate.

As volumes of sediment were calculated from the 3D thickness map, we infer that sediment fluxes previously used are the best estimate that can be obtained. However these volumes are assigned to a source in the model that relies on a strong assumption: sediment source is $100 \%$ terrigenous. The percentage of carbonates in the sediment supply controlled by the borehole data is less than $20 \%$ for the pre-Messinian Miocene and Plio-Pleistocene. This part, included as terrigenous input fluxes in the model, is insufficient to explain the amplitude of mismatches ( $50 \%$ for the Plio-Quaternary thickness).

The relative contribution of the three sedimentary sources may have changed through time, inducing local variations in thickness, but the final volume of deposits (calculated from 3D thickness map) would not change. Moreover no significant local difference in the 3D thickness distribution is observed between isopach maps and model results.

We consequently infer that the mismatch between the observed and modelled Miocene interval is not related to the fluxes and relative distribution of the sources. We thus investigate a possible change in the subsidence rate. 
We suggest that the subsidence rate in the basin is slower than $500 \mathrm{~m} / \mathrm{Myr}$ during the Miocene and conversely it is faster (more than $500 \mathrm{~m} / \mathrm{Myr}$ ) during the Pliocene and Pleistocene. This means that the margin would be submitted to an increase of subsidence that occurs during the Pliocene and Pleistocene, both on the shelf and in the basin. This trend is in agreement with the total subsidence estimated in two-dimensions by Rabineau et al. (2014), since $5.7 \mathrm{Ma}$ in the centre of the basin, which may have reached up to $960 \mathrm{~m} / \mathrm{Myr}$ (+/- $40 \mathrm{~m} / \mathrm{Myr}$ ). This would imply a 1,000 m subsidence of the basin over $15 \mathrm{Ma}$ (from $20 \mathrm{Ma}$ to $5.7 \mathrm{Ma}$ ) and a similar subsidence for only the last $5.7 \mathrm{Ma}$. In this case, we can calculate a post-rift subsidence rate in the centre of the basin before $5.7 \mathrm{Ma}$ of $300 \mathrm{~m} / \mathrm{Myr}$, three times lower than the subsidence rate for the last $5.7 \mathrm{Ma}$. This rate is in perfect agreement with the Miocene pre-crisis (before $5.96 \mathrm{Ma}$ ) subsidence rate of $335 \mathrm{~m} /$ Myr estimated by Lofi (2002); its order of magnitude is also the same (255 m/Myr) as the one calculated by Bache (2008) for the same time-span. The huge amount of salt and detrital deposits induces heavy loading in the basin that may partially explain the increase of subsidence rate during or after the Messinian salinity crisis.

The average sediment flux during the Pliocene and Pleistocene is three times greater than average sediment flux during the Miocene, before the Messinian (Figure 2B) (Leroux, 2012). This overall increase probably also contributed to enhance the subsidence of the margin. However, the extreme Messinian event with a huge sea-level drop, ensuing erosion of the shelf, and huge amount of deposits in the deep basin also induces a very strong isostatic rebound of the boarders of the margin that was measured for the first time on the outer shelf (Rabineau et al., 2014). This isostatic rebound reaches $1.3 \mathrm{~km}$ in the Aude-Herault outer shelf during the Messinian (i.e. $1.8 \mathrm{~km} / \mathrm{Myr}$ with a $0.7 \mathrm{Ma}$ duration for the crisis). The variable amplitude of these movements along the shelf complicates the reading of the pre-Messinian Miocene subsidence and could explain the relatively low Miocene subsidence rates we have estimated on the shelf and their variations from West to East. In such a case, we could explain the lower Miocene subsidence rate on the Eastern shelf by an isostatic rebound with higher amplitude on the Rhodanian shelf relative to the Pyreneo-Languedocian shelf. This could also result from the higher erosive processes in the Rhodanian Messinian valley area, as the Rhône is the second major River in the Mediterranean Sea (its incision during Messinian time has been mapped onland and shows a deep, over $1 \mathrm{~km}$, incision of the Rhône subaerial canyon) and its sediments transfer downstream towards the Eastern shelf during the Messinian Salinity Crisis.

The differences between East and West of apparent Miocene subsidence may be explained by tectonics.

The NE-SW structural direction observed on the shelf of the Gulf of Lion corresponds to the direction of faults inherited from the Variscan orogeny (Arthaud and Matte, 1977), which were reactivated during Pyrenean compression and at the end of the Miocene (Gorini et al., 1991; Mauffret et al., 2001; Gorini et al., 2005). A regional uplift also affected the post-rift (postLanghian) hinterland of the Gulf of Lion. After the Burdigalian-Langhian and before the Messinian, the reactivation of faults, such as the Cevennes fault, uplifted the Hérault basin and the onshore part of the East-margin of the Gulf of Lion (Séranne et al., 2002). In contrast, there are no significant tectonics post-Pliocene. The Eastern shelf of the offshore margin might also be affected by Miocene inversion, which could explain its marked topographic highs and its low apparent subsidence rate over the Miocene.

We have therefore run three-dimensional modelling in order to check the sediment geometries that are reproduced from this latest post-rift subsidence history. We applied a $300 \mathrm{~m} / \mathrm{Myr}$ vertical subsidence rate in the basin on the $20 \mathrm{Ma}-5.7 \mathrm{Ma}$ interval, followed by a $1000 \mathrm{~m} /$ Myr subsidence rate for the last 5.7 Ma. We have kept all other input parameters unchanged. Miocene subsidence rate on the shelf has been also reduced by two thirds, 
whereas the Plio-Pleistocene subsidence rate has been increased by the same order. We have used the Haq et al., (1987) eustatic curve. Results of this modelling (Figure 10) show that the architecture of the post-rift margin is better reconstructed than previously. On the shelf we still can still reproduce the progradation trend, followed by a progradationaggradation trend, respectively, during the Pliocene and Pleistocene. We also reproduce the deepening of the paleobathymetries in the basin throughout the pre-Messinian Miocene. Thicknesses of Miocene deposits are reduced; furthermore, thicknesses of major stratigraphic intervals are much more successfully reproduced even if Messinian deposits thicken in the distal part of the deep basin. This is due to the sediment influx, in particular the mixed detrital, evaporite, and salt deposits (in red and gray on Figure 10), which can't be distributed further and accumulate at the edge of the simulated box.

Western Mediterranean basins and margins have undergone a transition into Late Neogene basin inversion (e.g. Roure et al., 2013). Increase in the level of intraplate compression in the Northern Atlantic region could explain the observed rapid phases of Plio-Quaternary subsidence after a phase of quiescence (Kooi et al., 1992).

Moreover, in the Gulf of Lion, sediment flux during Pliocene (after $5.33 \mathrm{Ma}$ ) is 3 times higher than the flux in the Miocene. This increasing sediment load, driven by climate or tectonic, may therefore play an important role in the increased subsidence.

However, since 2004, many studies on passive margins, which are not in back-arc setting nor in inversion, have shown a delayed subsidence which increases long after the breakup: the thinning process seems to maintain the system in a high position until, at least, the breakup. In many margins, the presence of carbonates overlying the salt layer seems to show that this shallow environment lasted after the break-up. The subsidence is therefore delayed, as on Spitzberg Margin (Ritzmann, et al., 2004), on Iberia-Newfoundland Margins (PeronPinvidic \& Manatschal, 2008), on Morocco Margin (Labails et al., 2009), on Brazilian margins (Aslanian et al., 2009), on Angola margin (Moulin et al., 2005) or on the Gulf of Lion margin (Bache et al., 2010; Aslanian et al., 2012; Moulin et al., in press). The subsidence rate then seems to increase rapidly. This occurrence shows that the thermal process, which probably maintained in the high position the margin, is a general parameter in the thinning continental crust process (Aslanian et al., 2009; Huismans \& Beaumont, 2011, 2014; Aslanian et al., 2012). The general character of the delayed subsidence followed by an increased subsidence rate (during Plio-Quaternary here) implies probably another, deeper contribution like a lithosphere driven process as proposed by Aslanian et al. (2009) and Huisman \& Beaumont (2011) whithout excluding basin inversion process and/or sediment overloading.

Further work will better constrain the chronostratigraphy during the Pre-Messinian, in order to focus on the detailed restitution of the geometry of seismic reflectors during the Miocene.

As we have seen above, the knowledge of the entire post-rift evolution of the Gulf of Lion margin also needs the quan tification of Messinian isostatic readjustments, both in the basin and on the shelf. Then, further modelling will allow us to try to individualize and estimate the different vertical components of the total subsidence we have estimated in this study (such as the elastic flexure, isostatic rebound, loading, thermal subsidence, etc...). Threedimensional quantification of the flexure, which probably varies from one domain to another as a function of the nature and thickness of the underlying crust, would provide information about crustal behaviour and rheology. Modelling of the Messinian event also needs to be more constrained. Our simulation is one valid scenario, however it does not mean that it is the only one. The exact timing and amplitude for the sea-level fall and reflooding, as well as the timing and degree of evaporitic precipitation, are still discussed nowadays (CIESM, 2008). Moreover, a more realistic way to control the evaporite deposits would be to couple 
the stratigraphic simulation with a geochemical model for which all the parameters controlling evaporitic precipitation are constrained (concentrations, influx, cycles, and climatic parameters). However, these more sophisticated models would have calibration problems, as the nature of the sediment below the salt is still unknown.

\section{Conclusion}

In this study, we quantified the three-dimensional evolution of post-rift subsidence on the Gulf of Lion margin using sedimentary paleomarkers. We have shown that the subsidence of the post-rift sediments increases across the margin, with three different domains of subsidence correlated with deep structural domains. The continental crust domain of the shelf and slope is tilted, with a higher inclination on the slope where the thinning of the crust is greater. Downslope in the deep basin, the transitional crust domain is involved in a purely vertical subsidence with a mean post-rift rate of $500 \mathrm{~m} / \mathrm{Myr}$, with a higher subsidence rate during the last $5 \mathrm{Ma}$ (around $1000 \mathrm{~m} / \mathrm{Myr}$ ) than during the Miocene (around $300 \mathrm{~m} / \mathrm{Myr}$ ). Pliocene and Pleistocene subsidence rates on the shelf are constant through time $\left(0.16^{\circ} / \mathrm{Ma}\right)$ with a hingeline located around $20 \mathrm{~km}$ landward of the present-day coastline. This rate is unchanged from West to East, whereas the Miocene subsidence rate seems to vary in space (it appears almost nonexistent on the Rhodanian platform). Yet whatever the location on the shelf, the subsidence rate increases during the Pliocene and Pleistocene. We have highlighted that the vertical movements of the recent sedimentary record (over the last $5 \mathrm{Ma}$ ) are still completely reflecting the underlying rheological structure. Recent sediment markers are therefore important for studying and understanding the behaviour of the deep underlying crust.

The knowledge of sediment supply and subsidence history allowed us to model the threedimensional post-rift evolution of this passive margin. The use of a stratigraphic model allowed us to successfully test the validity of our geological model. However, our stratigraphic study is restrained to the Messinian, Pliocene, and Pleistocene. Now, Miocene stratigraphic markers need to be identified and dated in more detail to quantify the evolution of Miocene fluxes and subsidence. We also need to quantify and model the Messinian isostatic readjustments to better constrain the Miocene vertical movements of the margin. Future planned work also involves studying the stratigraphic record of the conjugate West Sardinian margin. The simultaneous developments of DIONISOS should then enable us to simulate both syn- and post-rift sequences of conjugate margins with the creation of new oceanic crust in the middle of the rift system.

\section{Acknowledgements}

This research was funded by CNRS, IFREMER, UPMC, and the GRI (Groupement Recherche et Industry) Méditerranée, with additional support from the French ActionsMarges program, and the CNRS-INSU SYSTER program (EROGOL). This work also benefited from the Labex Mer initiative, a State Grant from the French Agence Nationale de la Recherche (ANR) in the Program "Investissements d'avenir » with the reference ANR-10LABX-19-01, and Labex Mer. Stratigraphic simulations were performed with IFP-Energies Nouvelles DIONISOS software, kindly made available to the University of Brest. We also thank Beicip-Franlab for providing access and support in using DionisosFlow. Stratigraphic interpretations were performed with Kingdom Suite software, kindly made available to the University of Brest. The authors are grateful to Virginie Gaullier and an anonymous reviewer for their thoughtful comments on an earlier version of the manuscript. 
The final manuscript also greatly benefited from the comments and advices from Michel Seranne (Guest Editor). The authors are also grateful to Katalin Kovacs for post-editing the English style.

\section{Figure captions}

Figure 1: Location of the study area, dataset, and bathymetry of the Gulf of Lion (modified from Rabineau et al., 2014 and Berné et al., 2002). Triangles correspond to industrial wells. Circles correspond to OBS (Sardinia campaign) and ESP data.

Figure 2: A) Compilation of sea-level curves applied into the post-rift stratigraphic model of the Gulf of Lion margin. From Haq et al. (1987) (dashed line) and Miller et al. (2005) (continuous line). See the text for more explanation. B) Evolution of detrital sediment fluxes since $24 \mathrm{Ma}$ for the Gulf of Lion margin. From Leroux (2012).

Figure 3: A) Location of the ten synthetic vertical sections (A to J) built from the isobath maps of all the studied seismic markers. The bathymetric map built from seismic lines is superimposed. B) NE-SW strike section I showing seismic markers used in this study. The hinge lines delimiting subsidence domains are highlighted by grey area. We note that reflectors on the shelf and slope show a basin geometry with a maximum subsidence located in the center of the section.

Figure 4: Quantification of the post-rift subsidence on the shelf of the Gulf of Lion from extracts on sections $B, C$, and $E$. Location of these extracts are indicated with bold lines on the map (bottom left corner). Hinge-lines are identified by grey areas, successive offlapbreaks by shaded squares. The Pliocene and Pleistocene subsidence rate on the shelf is constant through time and appears higher than the Miocene subsidence rate. We can note that Miocene subsidence rate is lower on the Eastern platform. See the text for more explanation. Numbers on the right side of each section indicate the sedimentary thickness between stratigraphic markers, duration of the corresponding interval is written in brackets.

Figure 5: Vertical dip sections B, C, D, and E (locations on Figure 3A). Slope-breaks in the morphology of the paleomarkers are indicated by different symbols (squares and circles), the same as those used on Figure 4. Hatching on each section corresponds to the hinge-lines delimiting the different domains of subsidence.

Figure 6: A) Map of the post-rift subsidence built from the analysis of sedimentary markers. This map is applied into a stratigraphic model, DIONISOS. Hinge-lines are indicated. B) The structural domains highlighted by geophysical data [Moulin et al., this issue] and the geometries of the post-rift sedimentary pile are reported along a NW-SE dip line-drawing.

Figure 7: Comparison between the final architecture of the margin and the deposit bathymetries predicted by the model with the two sea-level variations scenarios. A: Seismic profile ECORS (time-depth converted). See position on Figure 1 and the seismic profile ECORS (second twtt) in Supplement Material. B1 and C1: Deposit depths predicted by DIONISOS in the respective simulations with the sea-level curves of Haq et al. (1987) and Miller et al. (2005). B2 and C2: synthetic seismic lines extracted from the respective simulations with sea-level curves of Haq et al. (1987) and Miller et al. (2005). See the text for 
more explanation. Velocities used for building synthetic seismic lines for sand, shale, and evaporite are respectively $4000 \mathrm{~m} / \mathrm{s}, 3000 \mathrm{~m} / \mathrm{s}$, and $4500 \mathrm{~m} / \mathrm{s}$. Respective densities for the same lithologies are 2.3, 2.2, and 2.2. D: Seismic profile ECORS (second twtt and vertical exaggeration $\mathrm{X10}$ ) with major stratigraphic intervals (yellow: basement, blue: Pre-Messinian Miocene, red: Messinian, pink: Messinian salt, uncolored: Pliocene and Pleistocene). Note that for this simulation the time-step used cannot distinguish between Messinian subunits.

Figure 8: Comparison between (A) sediment thickness map above the basement built from seismic markers (converted in meters) and (B) thickness map above basement output the simulation. Black box on the geographical map (right) indicates the boundaries of the simulated basin. The simulation successfully reproduced the order of magnitude of total postrift thickness map. See the text for more explanation.

Figure 9: Comparison between (A) a regional seismic profile from Bache (2008) (See position on Figure 1) and (B) the same seismic profile extracted by DIONISOS from modelling of the Messinian salinity crisis. Note that the vertical scale units are respectively in seconds (twtt) in A and in metres in B. On this synthetic seismic line (B), the impedance contrasts (in red and blue scale) highlight the same discontinuities we observed on the seismic profile A. The final simulated present-day topography (in blue-scale as function of the depth) is superimposed on the synthetic section. (C) Three-dimensional block showing the deposit paleobathymetries predicted by the model. The scenario of sea-level variations used into the model is illustrated on the left. Chrono-horizons are reported both on the eustatic curve (colored circles) and on the three-dimensional block (colored lines).

Figure 10: Results of the final three-dimensional simulation of the post-rift evolution of the Gulf of Lion margin. The subsidence rate adopted in the basin is $300 \mathrm{~m} / \mathrm{Myr}$ for the Miocene until 5.7 Ma and $1000 \mathrm{~m} / \mathrm{Myr}$ after. Modelling is done using the sea-level curve from Haq et al. (1987). (A). Deposit bathymetries predicted by DIONISOS. (B) Facies predicted by DIONISOS.

\section{References}

AFILHADO A., MOULIN M., ASLANIAN D., SCHNÜRLE P., KLINGELHOEFER F., NOUZÉ H., RABINEAU M., LEROUX E. \& BESLIER M.-O. (Submitted). - Deep crustal structure across a young 1 passive margin from wide-angle and reflection seismic data (The SARDINIA Experiment) - II. Sardinia's margin. - Bull. Soc. Géol. France, ILP Special volume.

ALLEN P.A \& ALLEN J.R. (1990). - Basin Analysis: Principles and Applications. - Blackwell Scientific Publications, Oxford. 451pp.

ALLEN P. \& ALLEN J. (2005). - Basin analysis, Principles and Applications, Blackwell Publishing Ltd, Second Edition, 549 pp.

ALOISI J.-C. (1986). - Sur un modèle de sédimentation deltaïque. Contribution à la connaissance des marges passives. - Thèse de Doctorat, Université de Perpignan, 162 pp. 
ARTHAUD F. \& MATTE P. (1977). - Late Paleozoic strike-slip faulting in Southern Europe and Northern Africa: result of a right lateral shear zone between the Appalachians and the Urals. - Bull. Soc. Geol. Amer. 88, 1305-1320.

ASLANIAN D., MOULIN M., OLIVET J.-L., UNTERNEHR P., MATIAS L., BACHE F., RABINEAU M., NOUZÉ H. \& KLINGELHOEFER F. (2009). - Brazilian and african passive margins of the central segment of the south atlantic ocean: Kinematic constraints.Tectonophysics, 468, 98-112.

ASLANIAN D., RABINEAU M., KLINGELHOEFER F., MOULIN M., SCHNURLE P., GAILLER A., BACHE F., LEROUX E., GORINI C., DROXLER A., EGUCHI N., KURODA J., ALAIN K., ROURE F., \& HAQ B. (2012). - Structure and evolution of the Gulf of Lion: The Sardinia seismic experiment and the GOLD (Gulf of Lion Drilling) project. - Leading Edge, 31, 786-792.

BACHE F. (2008). - Evolution oligo-miocène des marges du micro-océan liguro-provençal, $\mathrm{PhD}$ thesis, - Thèse de Doctorat de l'Université de Bretagne Occidentale, 328p., http://www.ifremer.fr/docelec

BACHE F., OLIVET J.-L., GORINI C., RABINEAU M., BAZTAN J., ASLANIAN D. \& SUC J.P. (2009). - Messinian erosional and salinity crises: View from the provence basin (gulf of lions, western mediterranean). - Earth Planet. Sci. Lett. 286, 139-157.

BACHE F., OLIVET J.-L., GORINI C., ASLANIAN D., LABAILS C. \& RABINEAU M. (2010). Evolution of rifted continental margins: the case of the Gulf of Lion (Western Mediterranean Basin). - Earth Planet. Sci. Lett., 292, 345-356.

BACHE F., POPESCU S.M., RABINEAU M., GORINI C., SUC J.P., CLAUZON G., OLIVET J-L., RUBINO J-L., MELINTE-DOBRINESCU M.C., ESTRADA F., LONDEIX L., ARMIJO R., MEYER B., JOLIVET L., JOUANNIC G., LEROUX E., ASLANIAN D., BAZTAN J., DOS REIS A.T., MOCOCHAIN L., DUMURDZANOV N., ZAGORCHEV I., LESIC V., TOMIC D., CAGATAY M.N., BRUN J-P., SOKOUTIS D., CSATO I., UCARKUS G. \& CAKIR Z. (2012). A two step process for the reflooding of the Mediterranean after the Messinian Salinity Crisis. - Basin Research, 23, 1-29.

BASSETTI M.A., BERNÉ S., JOUET G., TAVIANI M., DENNIELOU B. FLORES J., GAILLOT A., GELFORT R., LAFUERZA S., SULTAN N. (2008). - The 100-ka and rapid sea level changes recorded by prograding shelf sand bodies in the Gulf of Lions (western Mediterranean Sea). - Geochem. Geophys. Geosyst., 9, Q11R05, doi:10.1029/2007GC001854.

BAZTAN J., BERNE S., OLIVET J.-L., RABINEAU M., ASLANIAN D., GAUDIN M., REHAULT J.-P. \& . CANALS M. (2005). - Axial incision: The key to understand submarine canyon evolution (in the western Gulf of Lion). - Marine and Petroleum Geology, 22, 805-826

BERNE S., ALOISI J.C., BAZTAN J., DENNIELOU B., DROZ L., DOS REIS T., LOFI J., MEAR Y., RABINEAU M. \& SATRA C. (2002). - Notice de la carte morpho-bathymétrique du Golfe du Lion. IFREMER et Région Languedoc-Roussillon, Brest.

BIGOT-CORMIER F., POUPEAU G. \& SOSSON M. (2000). - Dénudations différentielles du massif cristallin externe alpin de l'argentera (sud-est de la france) révélées par thermochronologie traces de fission (apatites, zircons). - Comptes Rendus de l'Académie des Sciences de Paris, 330, 363-370. 
CATUNEANU O., ABREU V., BHATTACHARYA J.P., BLUM M.D., DALRYMPLE R.W., ERIKSSON P.G., FIELDING C.R., FISHER W.L., GALLOWAY W.E., GIBLING M.R., GILES K.A., HOLBROOK J.M., JORDAN R., KENDALL C.G.ST.C., MACURDA B., MARTINSEN O.J., MIALL A.D., NEAL J.E., NUMMEDAL D., POMAR L., POSAMENTIER H.W., PRATT B.R., SARG J.F., SHANLEY K.W., STEEL R.J., STRASSER A., TUCKER M.E. \& WINKER C. (2009). - Towards the standardization of sequence stratigraphy. - Earth-Science Reviews, 92, 1-33.

CEDERBOM C., SINCLAIR H., SCHLUNEGGER F. \& RAHN M. (2004). - Climate-induced rebound and exhumation of the European Alps. - Geology, 32(8), 709-712.

CIESM (2008). -The Messinian Salinity Crisis from mega-deposits to microbiology-A consensus report. In: BRIAND F (Ed.), CIESM workshop Monograph, 33, 1-26.

CLAUZON G. (1982). - Le canyon messinien du Rhône : une preuve décisive du « dessicated deep-basin model ». - Bull. Soc. Geol. France, 24, 597-610.

CLAUZON G., SUC J.P., GAUTIER F., BERGER A. \& LOUTRE M.F. (1996). - Alternate interpretation of the Messinian Salinity Crisis: controversy resolved? - Geology, 24, 363-366.

CRAVATTE J., DUFAURE P., PRIM M. \& ROUAIX S. (1974). - Les sondages du golfe du lion : Stratigraphie, sédimentologie. - Mem. Compagnie Française des Pétroles, Paris, 7, pp 209-274.

DE VOOGD B., NICOLICH R., OLIVET J.L., FANUCCI F., BURRUS J., MAUFFRET A., PASCAL G., ARGNANI A., AUZENDE J.M., BERNABINI M., BOIS C., CARMIGNANI L., FABBRI A., FINETTI I., GALDEANO A., GORINI C.., LABAUME P., LAJAT D., PATRIAT P., PINET B., RAVAT J., RICCI LUCCHI F. \& VERNASSA S. (1991). - First deep seismic reflection transect from the Gulf of Lion to Sardinia (ECORS-CROP profiles in Western Mediterranean). In: Meissner, R. (Ed.), Continental Lithosphere: Deep seismic reflections. American Geophysical Union, 265-274.

DURRIEU DE MADRON X., ABDERRAZZAK A., HEUSSNER S., MONACO A., ALOISI J.C., RADAKOVITCH O., GIRESSE P., BUSCAIL R. \& KERHERVE P. (2000). - Particulate matter and organic carbon budgets for the Gulf of Lion (NW Mediterranean). - Oceanol. Acta, 23 (6), 717- 730.

FERRANDINI J., GATTACCECA M, FERRANDINI M., DEINO A. \& JANIN M. (2003). Chronostratigraphy and paleomagnetism of Oligo-Miocene deposits of Corsica (France): geodynamic implications for the liguro-Provence Basin spreading. - Bull. Soc. Geol. France, 174(4), 357-371.

DUVAIL C., GORINI C., LOFI J., STRAT P.L., CLAUZON G. \& DOS REIS, T.A. (2005). Correlation between onshore and offshore pliocene-quaternary system tracts below the roussillon basin (Eastern Pyrenees, France). - Mar. Petrol. Geol., 22, 747-756.

GAILLER A., KLINGELHOEFER F., OLIVET J. L \& ASLANIAN D. (2009). - Crustal structure of a young margin pair: New results across the Liguro-Provencal Basin from wide-angle seismic tomography. - Earth Planet. Sci. Lett., 286, 333-345.

GARCIA-ESTEVES J. \& LUDWIG W. (2003). - Transfert de matière en suspension et de carbone particulaire dans le bassin versant de la Têt (Sud de la France). In: SERVANT E., NAJEM W., LEDUC C. \& SHAKEEL A. (Eds), Hydrology of the Mediterranean and Semiarid Regions (Proceedings of an international symposium held at Montpellier, April 2003, IAHS Publication, no. 278. 
GATTACCECA J., DEINO A., RIZZO R., JONES D., HENRY B., BEAUDOIN B. \& VADEBOIN F. (2007). - Miocene rotation of sardinia: New paleomagnetic and geochronological constraints and geodynamic implications.- Earth Planet. Sci. Lett., 258, 359-377.

GLOTZBACH C., VAN DER BEEK P. \& SPIEGEL C. (2011). - Episodic exhumation and relief growth in the mont blanc massif, western alps from numerical modelling of thermochronology data. - Earth Planet. Sci. Lett., 304, 417-430.

GORINI C., VIALLARD P. \& DÉRAMOND J. (1991). - Modèle d'inversion structurale négative: la tectonique extensive post-nappe du fossé de Narbonne-Sigean (Corbières, Sud de la France). C.R. Acad. Sci. Paris, 312, 1013-1019.

GORINI C., MAUFFRET A., GUENNOC P. \& MARREC A.L. (1994). - Structure of the Gulf of Lion (northwest Mediterranean sea) : A review. In: MASCLE A. (Ed), Hydrocarbon and petroleum geology of France.- Special Publication of the European Association of Petroleum Geology, Springer-Verlag, Berlin 4, 223-243.

GORINI C., LOFI J., DUVAIL C., DOS REIS T., GUENNOC P., LE STRAT P. \& MAUFFRET A. (2005). - The Late Messinian salinity crisis and Late Miocene tectonism: interaction and consequences on the physiography and post-rift evolution of the Gulf of Lion margin. - Mar. Pet. Geol., 22, 695-712.

GUENNOC P., GORINI C. \& MAUFFRET A. (2000). - Histoire géologique du Golfe du Lion et cartographie du rift Oligo-Aquitanien et de la surface messinienne. - Géologie de la France, 3, 67-97.

GUILLOCHEAU F. (1991). - Modalités d'empilement des séquences génétiques dans un bassin de plateforme (Dévonien Armoricain): nature et distorsion des différents ordres de séquences de dépôts emboîtées. - Bull. Cent. Rech. Explor. Prod. Elf-Aquitaine, 15, 383410.

GRANJEON D. (1996). - Modélisation stratigraphique déterministe: conception et applications d'un modèle diffusif $3 \mathrm{~d}$ multilithologique, - Thèse de doctorat, Université de Rennes 1, 200 p.

GRANJEON D. \& JOSEPH P. (1999). - Concepts and applications of a 3-d multiple lithology, diffusive model in stratigraphic modelling. In: Numerical Experiments in Stratigraphy: Recent Advances in Stratigraphic and Sedimentologic Computer Simulation. - SEPM Spec. Pub. 62, Tulsa, 197-210.

GRANJEON D. \& WOLF S. (2007). - 3D stratigraphic modeling in complex tectonics area. Abstract of the AAPG Annual Convention and Exhibition. AAPG Search and Discovery Long Beach, California, USA, April 2007.

GRANJEON D. (2009). - 3D stratigraphic modeling of sedimentary basins. AAPG Search and Discovery, Abstract of the AAPG Annual Convention and Exhibition, Denver, Colorado, June 7-10, 2009.

HAQ B., HARDENBOL J. \& VAIL P. (1987). - Chronology of fluctuating sea levels since the triassic (250 million years ago to present). - Science, 235, 1156-1166.

HINDERER M. (2001). - Late Quaternary denudation of the Alps, valley and lake fillings and modern river loads.- Geodynamica Acta, 14, 231-263. 
HUISMANS R. \& BEAUMONT C. (2011). - Depth-dependant extension, two-stage breakup and cratonic underplating at rifted margins. - Nature, 473, 74-79.

HUISMANS R. \& BEAUMONT C. (2014). - Rifted continental margins: the case for depthdependent extension. - Earth and Planet. Sci. Lett., 407, 148-162.

JERVEY M.T. (1988). - Quantitative geological modelling of siliciclastic rock sequences and their seismic expressions. In: WILGUS C.K., HASTINGS B.S., ST KENDALL C.G., ROSS C.A. \& VANWAGONER J.C. (Eds.), Sea-Level Changes: An Integrated Approach. - SEPM Spec. Pub., 42, Tulsa, 47-69.

KOOI H., CLOETINGH S. \& BURRUS J. (1992). - Lithospheric Necking and Regional Isostasy at Extensional Basins. 1. Subsidence and Gravity Modeling with an Application to the Gulf of Lions margin (SE France). - J. of Geophys. Research, 97(B12), 17553-17571.

LABAILS C. \& OLIVET J.L. \& the Dakhla study Group (2009). - Crustal structure of the SW Maroccan margin from wide-angle and reflection data (The Dakhla experiment). Part B. -The tectonic heritage. - Tectonophysics, 468 (1-4), 83-97.

LE DOUARAN S., BURRUS J. \& AVEDIK F. (1984). - Deep structure of the North-West Mediterranean basin: results of two-ship seismic survey. - Mar. Geol., 55, 325-345.

LEROUX E. (2012). - Quantifications des flux sédimentaires et de la subsidence dans le bassin Provençal, Méditerranée Occidentale. PhD thesis, - Thèse de Doctorat de l'Université de Bretagne Occidentale, Brest, 455p.

LEROUX E., RABINEAU M., ASLANIAN D., GRANJEON D., GORINI C. \& DROZ L. (2014). Stratigraphic simulation on the shelf of the Gulf of Lion: testing subsidence rates and sealevel curves during Pliocene and Quaternary. - Terra Nova, doi: 10.1111/ter.12091

LISIECKY L. \& RAYMO M. (2005). - A Pliocene-Pleistocene stack of 57 globally distributed benthic $\delta^{18}$ O records. - Paleoceanography, 20, PA1003, doi:10-1029/2004PA001071.

LOFI J. (2002). - La crise de salinité messinienne: conséquences directes et différées sur l'évolution sédimentaire de la marge du golfe du lion. PhD thesis, - Thèse de Doctorat de l'Université des Sciences et Techniques de Lille I, Lille, 261p.

LOFI J., RABINEAU M., GORINI C., BERNE S., CLAUZON G., DE CLARENS P., DOS REIS T.A., MOUNTAIN G.S., RYAN W.B.F., STECKLER M.S. \& FOUCHET C. (2003). - PlioQuaternary prograding clinoform wedges of the western Gulf of Lion continental margin (NW Mediterranean) after the Messinian Salinity Crisis. - Mar. Geol., 198, 289-317.

LOFI J., DEVERCHERE J., GAULLIER V., GILLET H., GORINI C., GUENNOC P., LONCKE L., MAILLARD A., SAGE F. \& THINON I. (2011). - Atlas of the "messinian salinity crisis" seismic markers in the Mediterranean and Black Seas. - Commission for the Geological Map of the World (CGGMW) / Mémoires de la Société Géologique de France, n.s., 179, 72 pp.

MAUFFRET A., PASCAL G., MAILLARD A. \& GORINI C. (1995). - Tectonics and deep structure of the North-Western Mediterranean basin. - Mar. Petrol. Geol., 12(6), 645-646.

MAUFFRET A., DURAND DE GROSSOUVRE B., DOS REIS A.T., GORINI C. \& NERCESSIAN A. (2001). - Structural geometry in the eastern Pyrenees and western Gulf of Lion (Western Mediterranean). - J. Struct. Geol., 23, 1701-1726. 
MCKENZIE D. (1978). - Some remarks on the development of sedimentary basins. -Earth and Planetary Science Letters, 40, 25-32.

MILLER K.G., KOMINZ M.A., BROWNING J.V., WRIGHT J.D., MOUNTAIN G.S., KATZ M.E., SUGARMAN P.J., CRAMER B.S., CHRISTIE-BLICK N. \& PEKAR S.F. (2005). - The Phanerozoic record of global sea-level change. - Science, 310 (5752), 1293-1298. http://dx.doi.org/10.1126/science.1116412.

MITCHUM R.M. \& VAIL P. (1977). - Seismic stratigraphic interpretation procedure. In: C.E. Payton (Ed), Seismic stratigraphy - Applications to hydrocarbon exploration. AAPG memoir, 135-143.

MOULIN M., KLINGELHOEFER F., AFILADHO A., ASLANIAN D., SCHNÜRLE P., NOUZE H., BESLIER M.-O. \& FELD A. (Submitted). - Deep crustal structure across an young passive margin from wide-angle and reflection seismic data (The SARDINIA Experiment) - I. Gulf of Lion's margin, BSGF, ILP Special volume, in press.

PASCAL G., MAUFFRET A. \& PATRIAT P. (1993). - The ocean-continent boundary in the Gulf of Lion from analysis of expanding spread profiles and gravity modelling. - Geophys. J. Int., 113, 701-726.

PAUC H. (1976). - Comportement dynamique des matériaux en suspension. Etude de divers secteurs côtiers du Golfe du Lion. - Bull. Soc. Hist. Nat. Afr. Nord, 67, 151-170.

PAYTON C.E. (1977). - Seismic Stratigraphy. Applications to Hydrocarbon Exploration (Ed. by PAYTON C.E.), AAPG Mem., 27.

PERON-PINVIDIC G. \& MANATSCHAL G. (2008). - The final rifting evolution at deep magma-poor passive margins from Iberia-Newfoundland : a new point of view. -Int. J. Earth Sci., 98, 1591-1597.

PONT D. (1997). - Les débits solides du Rhône à proximité de son embouchure: données récentes (1994-1995). - Rev. Géogr. Lyon, 72, 23- 33.

POSAMENTIER H.W., JERVEY M.T. \& VAIL P.R. (1988a). - Eustatic controls on clastic deposition I. Conceptual framework. In: WILGUS C.K., HASTINGS B.S., KENDALL C.G.S.C., POSAMENTIER H.W., ROSS C.A. \& VAN WAGONER J.C. (Eds.), Sea-Level Changes: An Integrated Approach. - SEPM Spec. Pub., vol. 42. SEPM, Tulsa, 102-124.

POSAMENTIER H.W. \& VAIL P.R. (1988b). - Eustatic controls on clastic deposition II. Sequences and system tract models. In: WILGUS C.K., HASTINGS B.S., KENDALL C.G.S.C., POSAMENTIER H.W., ROSS C.A. \& VAN WAGONER J.C. (Eds.), Sea-Level Changes: An Integrated Approach. - SEPM Spec. Pub., vol. 42. SEPM, Tulsa, 125-154.

RABINEAU M. (2001). - Un modèle géométrique et stratigraphique des séquences de dépôs quaternaires de la plate-forme du golfe du lion : enregistrement des cycles glacioeustatiques de 100 000ans. PhD thesis, - Thèse de Doctorat de I'Université de Rennes 1/IFREMER, 392p., http://www.ifremer.fr/docelec

RABINEAU M., BERNÉ S., ASLANIAN D., OLIVET J.L., JOSEPH P., GUILLOCHEAU F., BOURILLET J.F., LEDREZEN E. \& GRANJEON D. (2005). - Sedimentary sequences in the Gulf of Lion: A record of 100, 000 years climatic cycles. - Mar. Pet. Geol., 22, 775-804.

RABINEAU M., BERNÉ S., OLIVET J-L, ASLANIAN D., JOSEPH P. \& GUILLOCHEAU F. (2006) - Paleosea-levels reconsidered from direct observation of paleoshoreline position 
during Glacial Maxima (for the last 500000 yr)- Earth and Planetary Science Letters, 252 (1-2), 119-137, DOI: 10.1016/j.epsl.2006.09.033.

RABINEAU M., LEROUX E., ASLANIAN D., BACHE F., GORINI C., MOULIN M., MOLLIEX S., DROZ L., REIS A.D., RUBINO J.-L., GUILLOCHEAU F. \& OLIVET J.-L (2014). - Quantifying subsidence and isostatic readjustment using sedimentary paleomarkers, example from the Gulf of Lion. - Earth Planet. Sci. Lett., 388, 1-14.

RADAKOVITCH O. (1995). - Etude du transfert et du dépôt du matériel particulaire par le $210 \mathrm{Po}$ et le $210 \mathrm{~Pb}$. Application aux marges continentales du Golfe de Gascogne (NE Atlantique) et du Golfe du Lion (NW Méditerranée). - Thèse de Doctorat, Université de Perpignan, 185 pages.

RITZMANN O., JOKAT W., CZUBA W., GUTERCH A., MJELDE R. \& NISHIMURA Y. (2004).- A deep seismic transect from Hovgard Ridge to Northwestern Svalbard across the continental-ocean transition : a shared margin study. -Geophys. J. Int., 157 (2), 603-702.

ROBIN C., GUILLOCHEAU F. \& GAULIER J.M. (1996). - Mesure des signaux eustatiques et tectoniques au sein de l'enregistrement sédimentaire d'un bassin intracratonique. Application au Lias du bassin de Paris. - C.R. Acad. Sci. Paris, 322, 1079-1086.

ROURE F.M., CASERO P. \& ADDOUM B. (2013). -Mesozoic and Cenozoic Basins Formation and Deformation along the North African Margin. - Search and Discovering Article \#30276, AAPG2013.

ROUSSIEZ V., ALOISI J.C., MONACO A. \& LUDWIG W. (2005). - Early muddy deposits along the Gulf of Lion shoreline: a key for a better understanding of land-to-sea transfer of sediments and associated pollutant fluxes.- Marine Geology, 222-223, 345-358.

SEMPÉRÉ R., CHARRIERE B., CAUWET G. \& VAN WAMBECKE F. (2000). - Carbon inputs of the Rhone River to the Mediterranean Sea: biogeochemical implications. - Glob. Biogeochem. Cycles, 14, 669-681.

SÉRANNE M., BENEDICTO A., TRUFFERT C., PASCAL G. \& LABAUME P. (1995). Structural style and evolution of the Gulf of Lion Oligo-Miocene rifting: Role of the Pyrenean orogeny. - Mar. and Petr. Geol., 12 (8), 809-820.

SERANNE M. (1999). - The Gulf of Lion continental margin (NW MEditerranean) revisited by IBS: an overview. In: DURAND B., JOLIVET L., HORVATH F. \& SERANNE M. (Eds.), The Mediterranean Basins: Tertiary Extension within the Alpine Orgogen. Special publication, Geological Society of London.

SERANNE M., CAMUS H., LUCAZEAU F., BARBARAND J., \& QUINIF Y. (2002).Surrection et érosion polyphasées de la bordure cévenol. Un exemple de morphogenèse lente. - Bulletin de la Société Géologique de France, 173(2), 97-112.

SERRAT P., LUDWIG W., NAVARRO B. \& BLAZI J.-L. (2001). - Variabilité spatio-temporelle des flux de matières en suspension d'un fleuve côtier méditerranéen: la Têt (France). - $C$. $R$. Acad. Sci,. 333, 389- 397.

SPERANZA F., VILLA I., SAGNOTTI L., FLORINDO F., COSENTINO D., CIPOLLARI P. \& MATTEI M. (2002). - Age of the corsica-sardinia rotation and liguro-Provence Basin spreading: new paleomagnetic and ar/ar evidence. -Tectonophysics, 347, 231-251.

STECKLER M.S., WATTS A.B. \& THORNE J.A. (1988). -Subsidence and basin modeling at the U.S. Atlantic passive margin. In: SHERIDAN RE. \& GROW J.A. (Eds), The Atlantic 
Continental Margin, U.S., Geological Society of America, The Geology of North America, Vol. I-2.

VAIL P.R., COLIN J.P., DU CHENE R.J., KUCHLY J., MEDIA VILLA F. \& TRIFILIEFF V. (1987). - La stratigraphie séquentielle et son application aux corrélations chronostratigraphiques dans le Jurassique du Bassin de Paris. - Bull. Soc. Géol. Fr., 8, 1301-1321.

VAN HINTE J.E. (1978). - Geohistory analysis: application of micropaleontology in exploration geology. - Am. Assoc. Pet. Geol. Bull., 62, 201-222.

WATTS A.B. \& RYAN W.B.F. (1976). - Flexure of the lithosphere and continental margin basins. -Tectonophysics, 36, 25-44. 


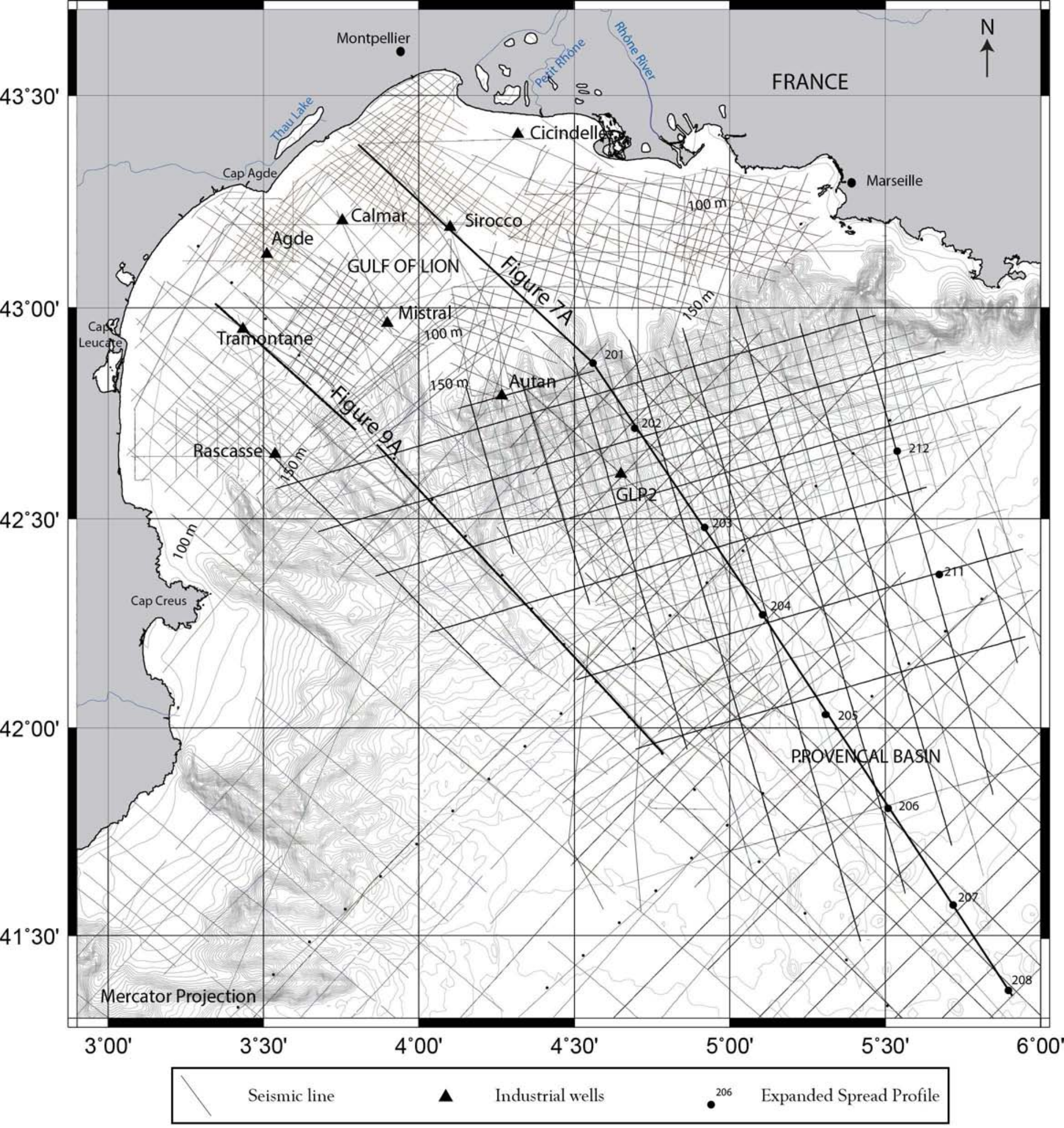

Leroux et al., Figure 01 
A) EUSTATISM

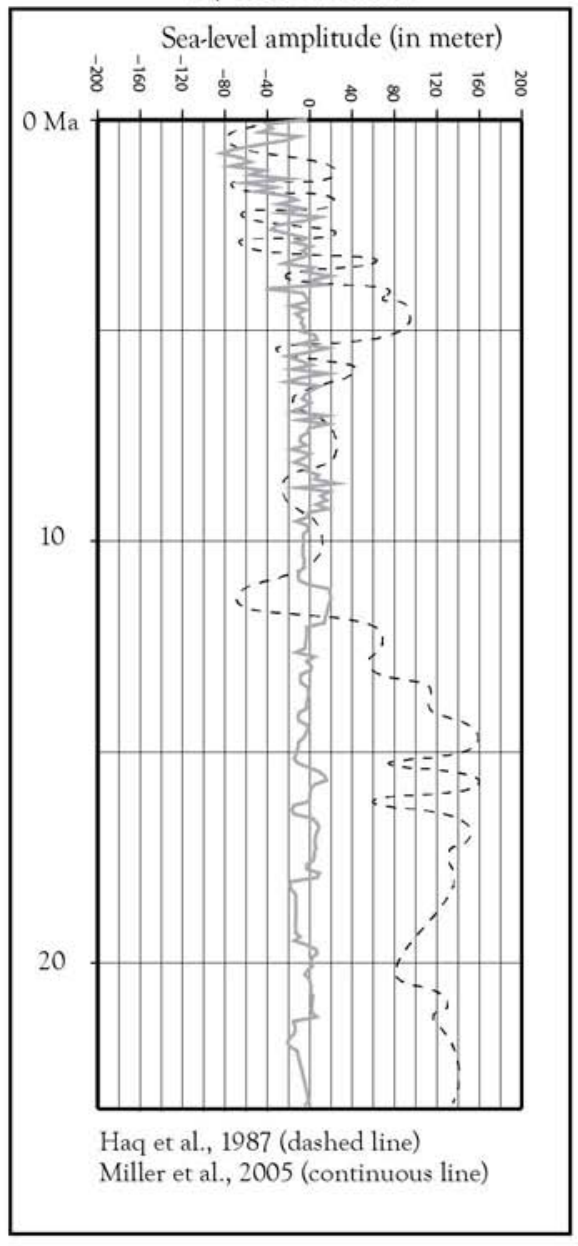

B) SEDIMENT SUPPLY

Sediment fluxes $\left(x 10^{3} \mathrm{~km}^{3} / \mathrm{Myr}\right)$

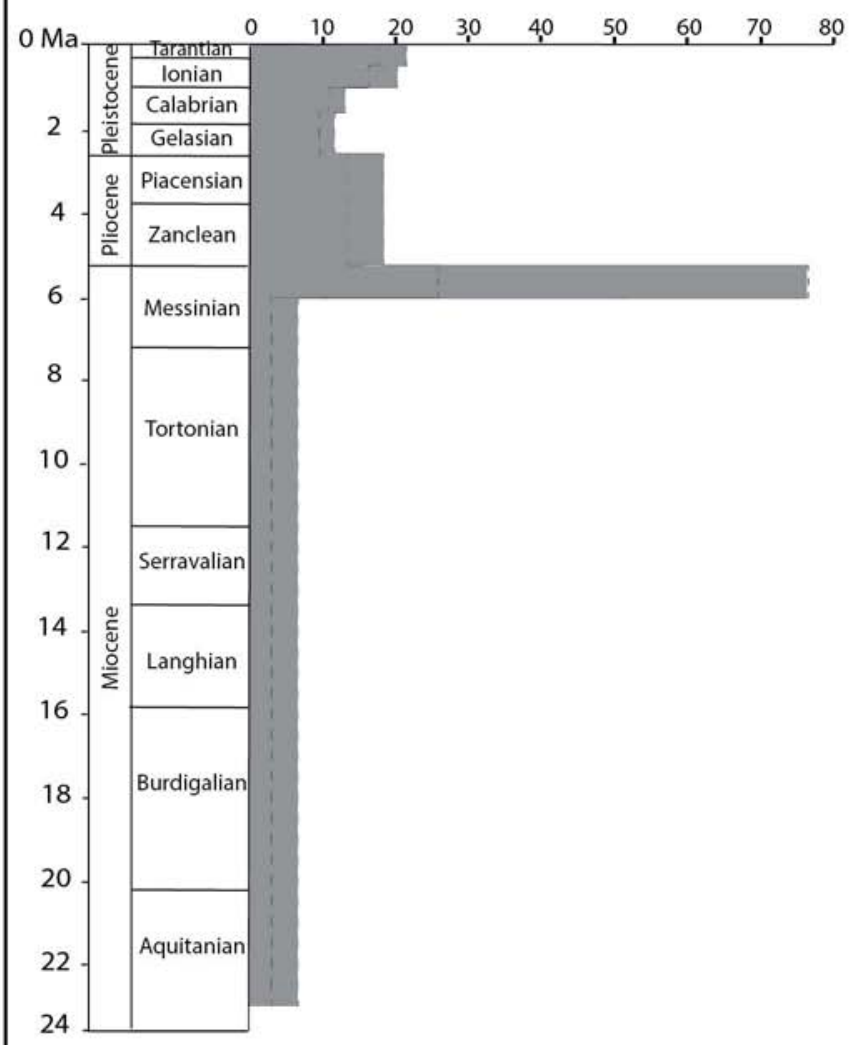




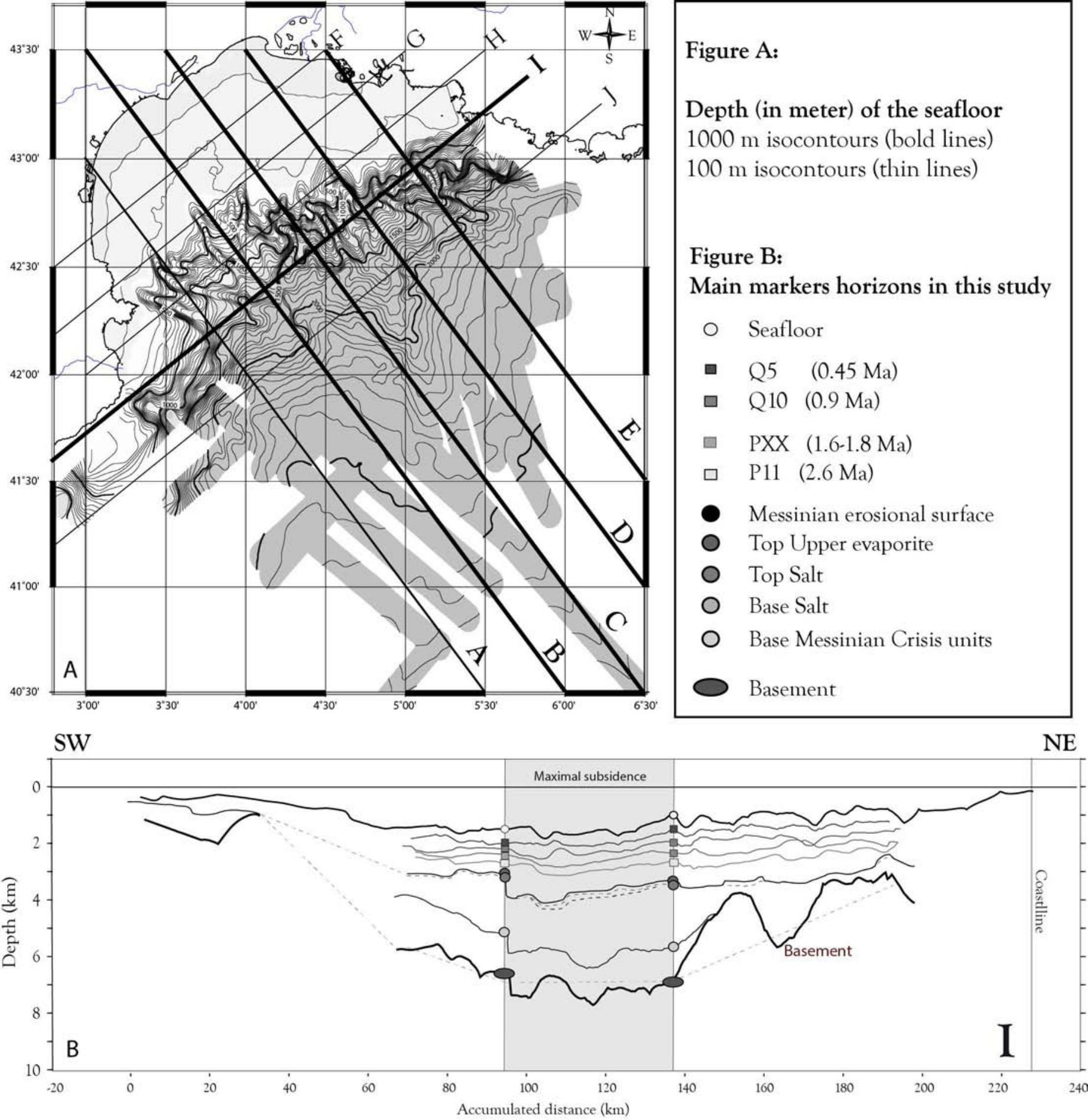




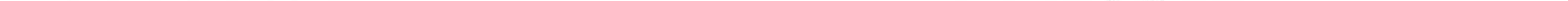




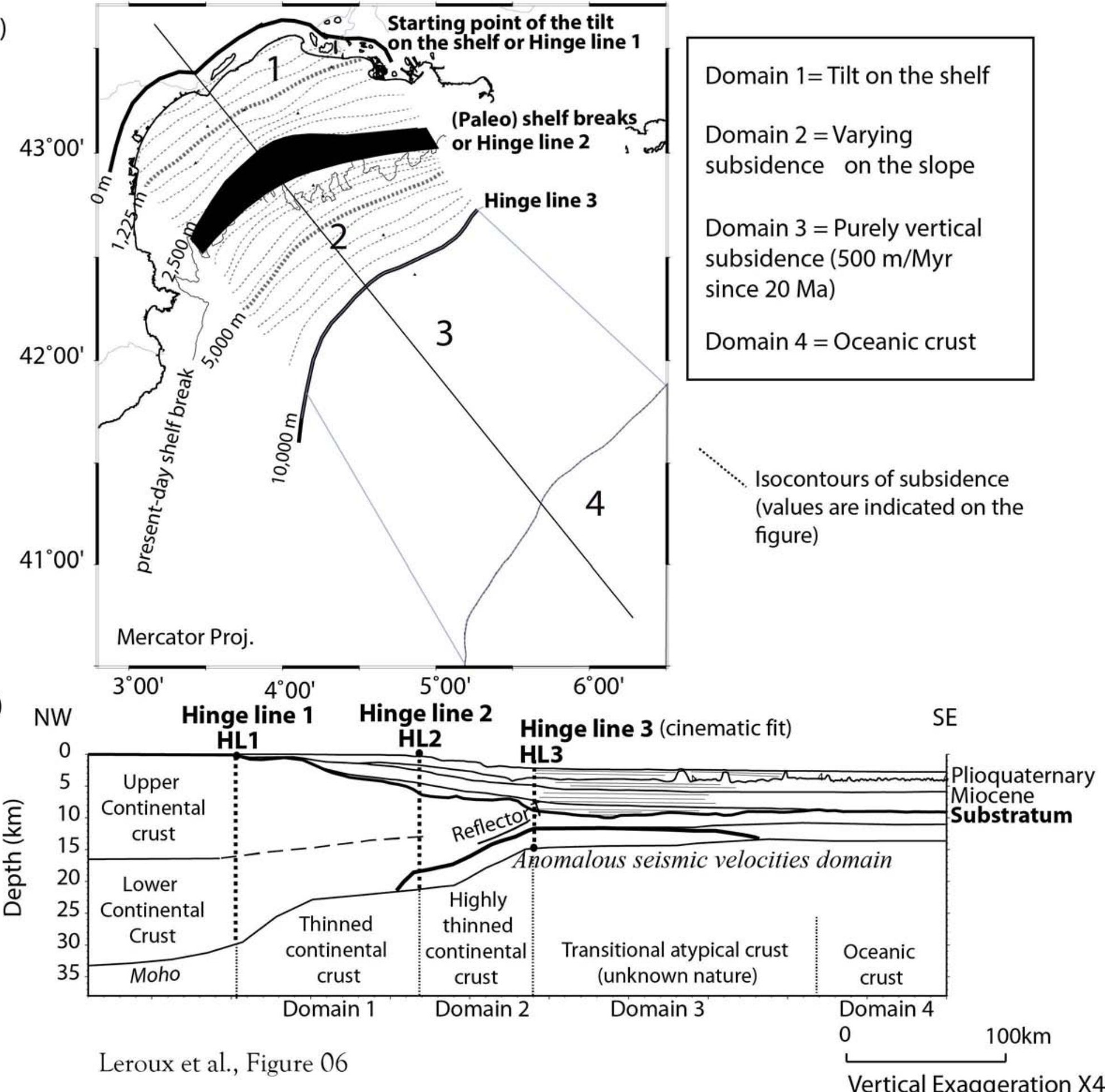

B) 


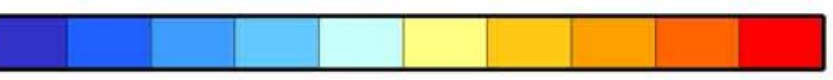

$\begin{array}{lllllllllll}0 & 500 & 1000 & 2000 & 3000 & 4000 & 5000 & 6000 & 7000 & 8000 & 8530\end{array}$

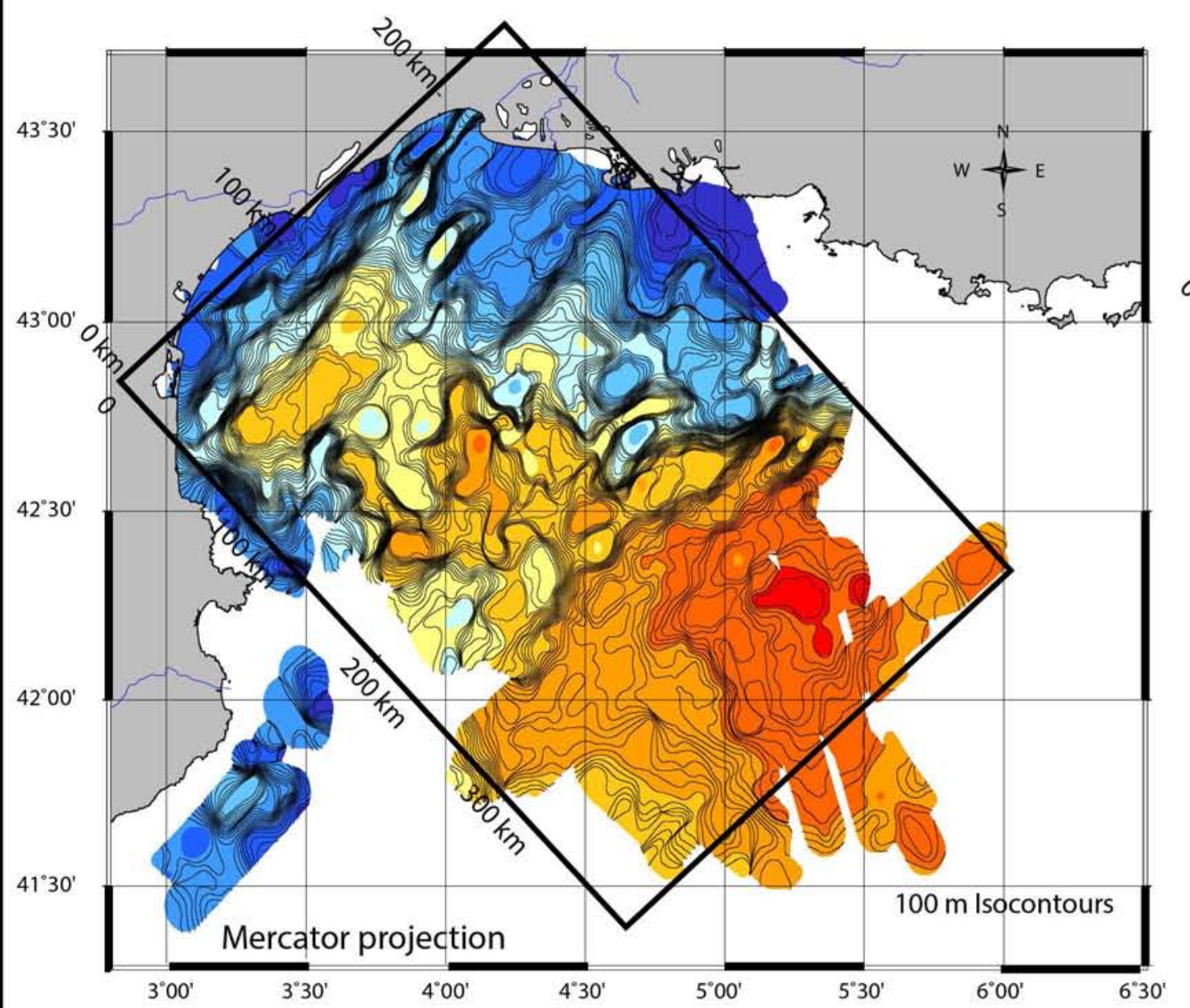

B) Simulated sediment sediment thickness above basement (m)
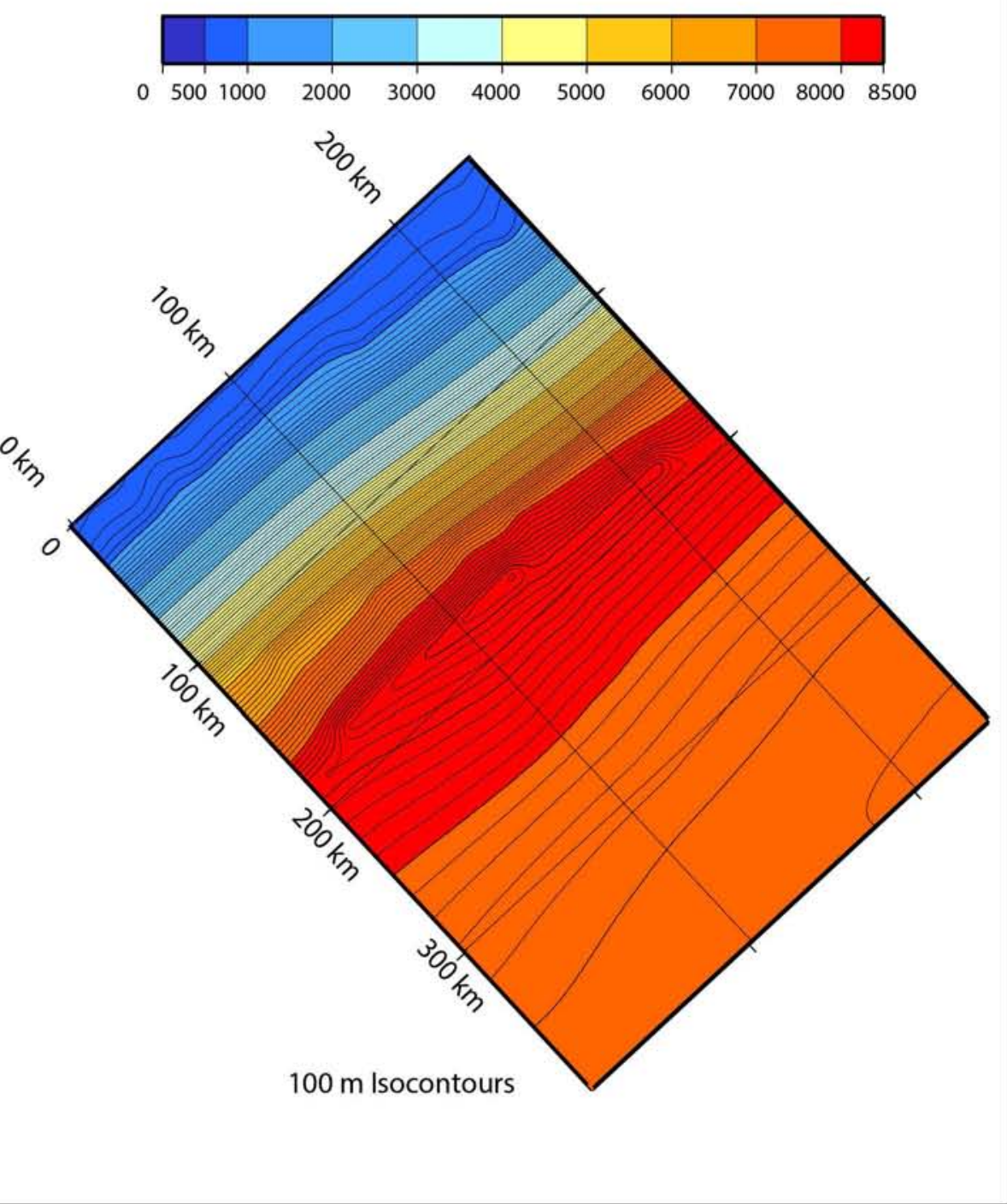

Leroux et al., Figure 08 

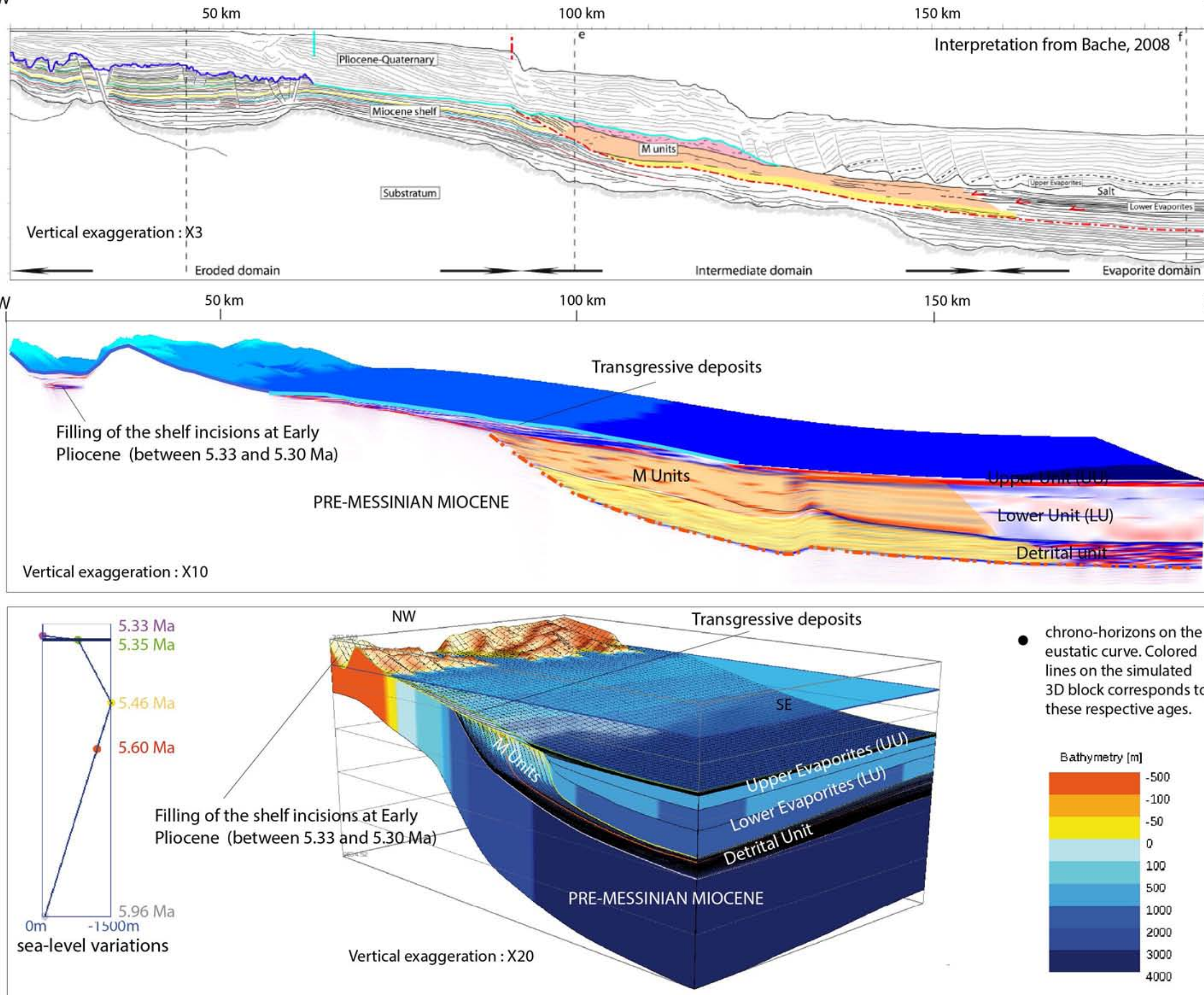

- chrono-horizons on the eustatic curve. Colored lines on the simulated $3 \mathrm{D}$ block corresponds to these respective ages.

Bathymetry [m]

Filling of the shelf incisions at Early

Pliocene (between 5.33 and 5.30 Ma) 
Sea level curve from Haq et al., 1987

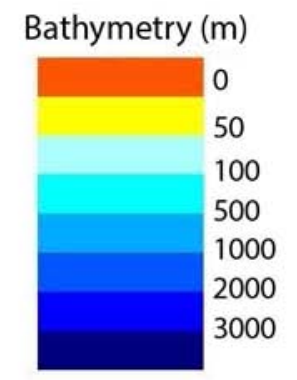

\section{Facies}

sand
silt
shale
salt
mixed
detrital
\& evaporites

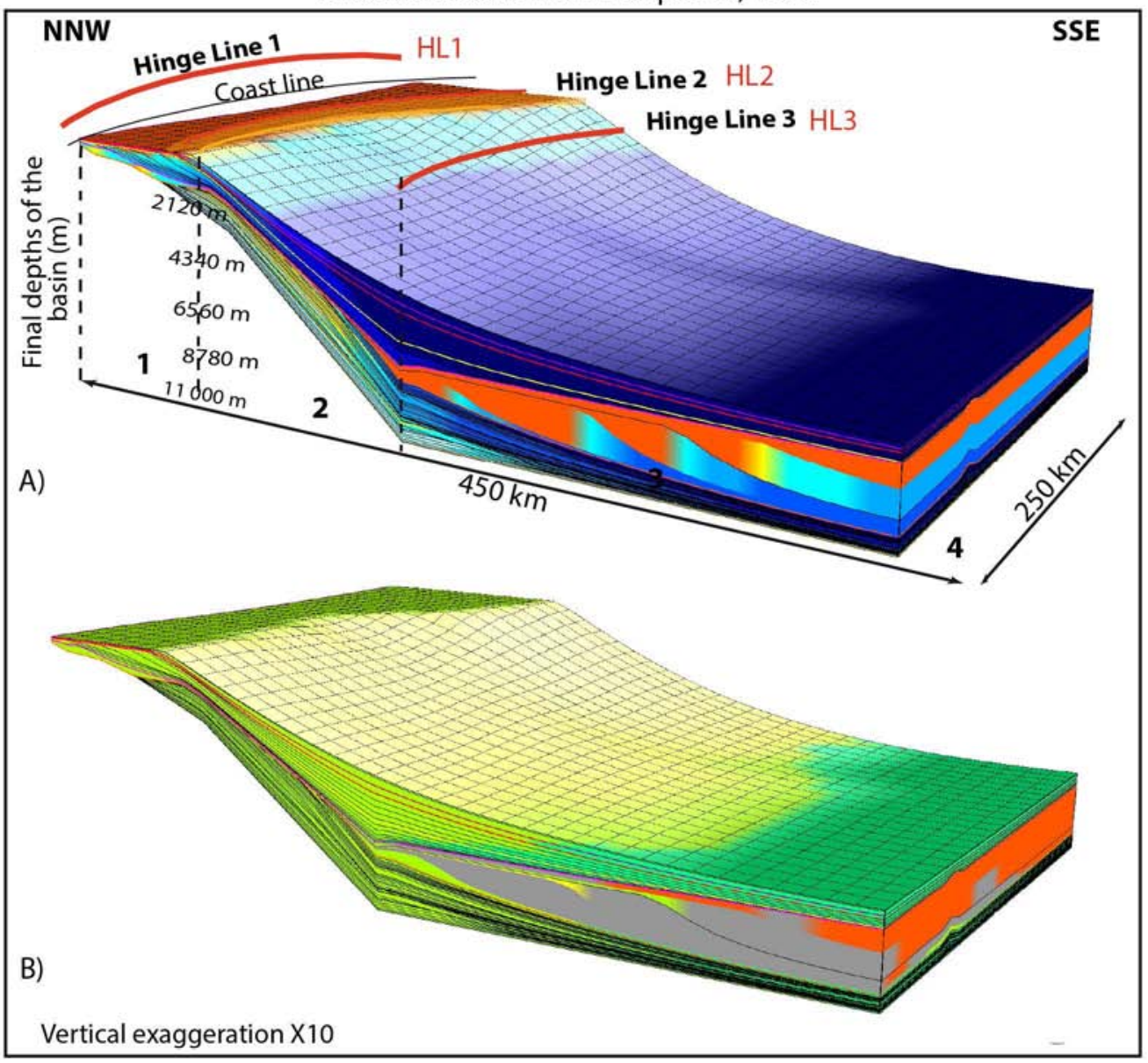

